\title{
Corporate heritage stewardship: A corporate marketing perspective
}

\author{
Mario Burghausen ${ }^{1}$ and John M.T. Balmer ${ }^{2}$
}

\begin{abstract}
${ }^{1}$ Dr Mario Burghausen is Lecturer in Marketing at the University of Essex, Colchester where his current research focuses, amongst his interest in corporate-level marketing issues in general, on corporate heritage and other past-related concepts.

${ }^{2}$ Professor John M.T. Balmer is Professor of Corporate Marketing at Brunel University, London, where he is the Director of the Centre for Research in Marketing, and Quondam Professor of Corporate Brand/Identity Management at Bradford University School of Management, England.
\end{abstract}

This is an earlier version of a journal article to be published by Emerald. Please refer to the published article for a definitive version and for citation purposes. This article is under the copyright (C) of Emerald Group Publishing Ltd. and permission has been granted for this version to appear here (http://repository.essex.ac.uk/). Emerald does not grant permission for this article to be further copied/distributed or hosted elsewhere without the expressed permission from Emerald Group Publishing Ltd.

\begin{abstract}
Purpose: Focusing on the nascent corporate heritage identity domain, this empirical study introduces the theory of corporate heritage stewardship. In particular, the research explores managers' collective understanding of their organisation's corporate heritage and how the latter is marshalled, and strategically represented, by them. The case study was undertaken in Great Britain's oldest extant brewery. Established in 1698 Shepherd Neame is one of UK's oldest companies.
\end{abstract}

Design/methodology/approach: Empirical research informed by a theory-building, case-study using qualitative data. This study draws on multiple sources of data generated through semi-structured interviews, the analysis of documents and non-participant observations. The analysis of data was facilitated by a multi-stage coding process and a prolonged hermeneutic interaction between data, emerging concepts, and extant literature.

Findings: Corporate heritage identity stewardship theory argues that the strategic enactment of a corporate heritage identity is predicated on a particular management mindset, which is meaningfully informed by three awareness dimensions expressed by managers (i.e. awareness of positionality, heritage, and custodianship). These awareness dimensions are underpinned by six managerial stewardship dispositions characterised by a sense of: (1) continuance; (2) belongingness; (3) self; (4) heritage; (5) responsibility; and (6) potency. The findings are synthesised into a theoretical framework of managerial corporate heritage identity stewardship.

Research limitations/implications: The insights from this empirical case study meaningfully advance our theoretical understanding of the corporate heritage identity domain. Whilst the empirical contribution of this study is qualitatively different from statistical/substantive generalisations, which seek to establish universal laws, the research insights are valuable in terms of theory-building in their own terms and are analytically generalisable. The insights from this study have the potential to inform further studies on corporate heritage identities, including research underpinned by a positivistic, and quantitative, methodology.

Practical implications: The findings have utility for corporate marketing management in that they illustrate how a collective corporate heritage mindset can both inform, as well as guide, managers in terms of their stewardship of their firm's corporate heritage identity. The theoretical framework is of utility in practical terms in that it reveals the multiple dimensions that are significant for management stewardship of a corporate heritage identity.

Originality/value: The research confirms and expands the notion of management stewardship in corporate identity in corporate marketing contexts by identifying how a multi-dimensional managerial mindset has constitutive and instrumental relevance. Moreover, this study identifies the distinct characteristics of this corporate identity type - corporate heritage identity - which are revealed to have a saliency for managers. Both insights underpin the corporate heritage identity stewardship theory explicated in this article.

Keywords: Corporate Heritage, Corporate Heritage Identity, Corporate Marketing, Corporate Identity, Case Study, Qualitative Research

Article Classification: Research paper 


\section{Corporate heritage identity stewardship: A corporate marketing perspective}

\section{Introduction}

This article introduces and explicates the theory of corporate heritage identity stewardship. Corporate heritage identities have recently been identified as a distinct type of institutional identity. They are distinct in that the identity traits of these organisations whilst ostensibly indelible (because they are of the, past, present and future) concurrently accommodate continuity and change: they are characterised by their relative invariance (Balmer, 2011b). As such, Balmer (2011b) -taking an instrumental perspective - maintains that corporate heritage identities, because of their distinct omni-temporal natures, require senior managers to comprehend their on-going governance responsibilities in terms of a stewardship role (i.e. corporate heritage identity stewardship), which is to be markedly different from the customary management function largely focussed on the short-term. Balmer (2011b) therefore argues that a key requisite for the successful stewardship of a corporate heritage identity requires managers to think, feel, and act as custodians.

Over recent years, corporate heritage as an organisational phenomenon, and its appropriation as a strategic resource for corporate-level marketing purposes, has increasingly attracted the attention of marketing scholars (Balmer et al., 2006; Urde et al., 2007; Blombäck and Brunninge, 2009; Wiedmann et al., 2011a, 2011b; Balmer 2011a, 2011b; Hudson 2011). The concept of corporate heritage refers to particular traits of an organisation that meaningfully link its past, present, and future by referring to some aspect of an organisation's past that is still deemed by current stakeholders to be relevant for contemporary concerns and purposes but that is concurrently perceived as worth to be maintained, nurtured, and passed on to future generations (Balmer 2011b).

Yet, within the nascent corporate heritage canon whilst the prima facie ubiquity of organisations featuring corporate heritage identity characteristics that are potentially managed in quite different ways has been noted (Balmer, 2011b; Blombäck and Brunninge, 2009) and the various defining dimensions of this distinct type of institutional identity have been discussed (Balmer, 2011b; 2013), to date, empirical insights and conceptual elaborations relating to the particularities of corporate heritage identity stewardship are absent. Hence, little is known about the aforementioned in empirical and 


\section{$28^{\text {th }}$ February, 2014}

theoretical terms, despite being suggested as a key requisite for the successful management of a corporate heritage identity, and this article seeks to address this gap in the literature.

Therefore, this article reports an empirical theory building study that seeks to advance the understanding of corporate heritage identity stewardship in theoretical and instrumental terms. Arguably, this study is believed to be first major empirical inquiry with this specific focus and makes a meaningful theoretical advance to the territory. In theoretical terms, this empirical study makes a contribution to the nascent corporate heritage field by revealing key interpretative dimensions pertaining to corporate heritage identity stewardship as understood by managers. We elaborate the research insights by outlining the theory of corporate heritage identity stewardship by way of a theoretical framework. In addition, we aim to provide instrumental insights by uncovering those traits that are important for corporate heritage identity stewardship.

Corporate heritage identity stewardship, as revealed by this study, can be explained in terms of a particular corporate heritage identity stewardship mindset which meaningfully informs the strategic enactment of a corporate heritage identity by managers. The managerial mindset represents the manner in which managers apprehend and relate to their organisation as a heritage institution affording them a propensity to act towards and on behalf of the organisation. As such, the corporate heritage identity stewardship mindset is characterised by three awareness dimensions expressed by managers (i.e. positionality, heritage and custodianship), which are underpinned by six managerial stewardship dispositions characterised by a sense of (1) continuance, (2) belongingness, (3) self, (4) heritage, (5) responsibility, and (6) potency. A theoretical framework - informed by the above - is introduced that has instrumental utility in explaining the multi-dimensional nature of corporate heritage identity stewardship necessary for the management of a corporate heritage identity.

At the outset it is important to note that our study is informed by moderate constructionist paradigmatic convictions (Blaikie, 2006, 2009) and, as such, can be classified as an interpretative theory/theoretical contribution (Charmaz, 2006). The significance of this theoretical contribution is in terms of providing insight in relation to emergent patterns and non-linear relations between concepts (Charmaz, 2006). Significantly, this mode of theoretical contribution is qualitatively different from theoretical insights which explicitly focus on deterministic explanations of causal linear relationships 
between variables (Charmaz, 2006). In terms of resultant theoretical frameworks, which both describe and explains how a phenomenon behaves (Lee and Lings, 2008), the nature of what constitutes description and explanation will differ as a consequence of the paradigmatic perspectives adopted by the researchers and which will, as a consequence, inform the mode of theoretical contribution (Charmaz, 2006; Blaikie, 2006, 2009).

Consequently, and for the sake of clarity, it is important to note that the theoretical framework presented in this article highlights patterns and multifaceted arrangements of concepts in a holistic fashion. The purpose of the resultant theoretical framework does not aim to specify directional relations between discrete variables in a reductionist way which characterises more positivist theoretical models (Blaikie, 2006, 2009)

The research was undertaken within the UK's oldest brewery - Shepherd Neame - and an in-depth theory building single case study design (using multiple forms of qualitative data) informed the study due to the underspecified character of the focal concept and its sparse empirical base. We adopt an explicit corporate marketing perspective in terms of positioning this study within marketing (Balmer 1998, 2001, 2011c; Balmer and Greyser, 2003, 2006; He and Balmer 2007a, 2013; Powell, 2011; Hildebrand et al ., 2011; Abratt and Kleyn, 2012) in that our study has an explicit corporate-level (rather than product and service level) focus.

Based on a review of the extant literature, the article continues by outlining the context within which the concept of heritage has been discussed within corporate marketing and marketing in general, before detailing several corporate heritage dimensions articulated in the extant literature and addressing the notion of corporate heritage stewardship in particular. Subsequently, the article provides the rationale for the study articulating its relevance and timeliness. After presenting the empirical background and articulating the methodological approach adopted, the empirical findings of the study are outlined and the theoretical contribution of this theory building research - the articulation of a theory of corporate heritage identity stewardship - is introduced. This theoretical contribution is represented, and elaborated, in the form of a theoretical model as noted above which advances our theoretical understanding of corporate heritage identity stewardship. Finally, the theoretical, practical, and research implications of our findings are outlined. 


\section{Corporate heritage brands and identities in context}

Corporate heritage as an institutional phenomenon emerged from research which explored monarchies (i.e. the institution represented by a Sovereign as Head of State and, more generally, by a Royal Family) as heritage institutions and as corporate heritage brands (Balmer et al., 2004, 2006; Balmer, 2009a). These seminal conceptual and descriptive studies relating to the corporate heritage phenomenon detailed the significance of the domain and provided an initial articulation of key corporate heritage traits. Arguably, two articles have been influential in providing the foundations for the field, which respectively focussed on monarchies (Balmer et al., 2006) and on corporate brands with a heritage (Urde et al., 2007).

Within the subject domain of corporate marketing (Balmer, 1998, 2011c; Balmer and Greyser, 2003, 2006), the idea has been advanced that corporate heritage brands (Balmer et al., 2006; Urde et al., 2007; Balmer, 2011a), and corporate heritage identities (Balmer, 2011b), represent distinct types of institutional brands and identities. While most companies on average only survive for a mere forty years (de Geus, 2002), there are, all the same, a sizable number of prominent business organisations with corporate brands and identities that are of considerable maturity (Urde et al., 2007; Blombäck and Brunninge, 2009). The track record of success - of these potential or actual heritage institutions sometimes spans the centuries (Urde et al., 2007; Urde, 2009; Stadler, 2011).

Both corporate heritage brands and corporate heritage identities draw on an organisation's institutional heritage (i.e. corporate heritage). However, a distinction is made in that corporate heritage identity is a much broader concept potentially relevant for all organisations imbued with an institutional heritage while a corporate heritage brand identity requires the strategic decision for a well-defined and enduring value proposition and covenant between the organisation and its stakeholders predicated on the corporate heritage identity of the organisation (Balmer 2013).

In this context it was argued that corporate heritage brands (Urde et al., 2007) and, more recently, corporate heritage identities (Balmer, 2011b), in order to survive and to remain salient, required ongoing management stewardship.

Heritage stewardship, it was advanced, is predicated on a particular managerial mindset which informs the enactment of these distinct institutional brands/identities (Urde et al., 2007; Balmer, 2011a). 
In more general and in instrumental terms, the management notion of stewardship is consistent with the custodial role accorded to management within the subject domain of corporate marketing in regard to corporate brands and corporate identities per se (Balmer, 2009b, 2011c, 2012b; Balmer and Greyser, 2003). From a more pronounced theoretical standpoint, this above perspective mirrors the increased interest in management cognitions and self-understanding in regard to corporate identities in general (He and Balmer, 2007b; 2013; He, 2012).

However, despite the growing reference made to corporate heritage within corporate marketing (Urde et al., 2007; Balmer, 2011a, 2011b; Hudson, 2011; Wiedmann et al., 2011a, 2011b) - a development accompanied by an increased interest in the strategic utility of historical references in general (Blombäck and Brunninge, 2009) - and brand heritage in consumer marketing (Aaker, 1996; Ballantyne, Warren and Nobbs, 2006; Liebrenz-Himes, Shamma and Dyer, 2007; Hakala, Lätti and Sandberg, 2011), the notion of corporate heritage brands and corporate heritage identities, from both theoretical as well as from instrumental perspectives, has received little academic and empirical scrutiny so far (Balmer, 2011b) and the particular managerial stewardship dimensions believed to be characteristic for such entities - albeit tentatively discussed by Urde et al. (2007) in regard to corporate heritage brands - remain, to a large degree, underspecified.

\section{The notion of heritage in marketing}

The importance of brand heritage in particular emerges as a key leitmotif within the marketing literature and it has been asserted that heritage is a key marketing asset (Ballantyne et al., 2006). For instance, within the marketing canon heritage is seen to be salient in regard to product brand identities (Aaker 1996; Liebrenz-Himes et al., 2007; Hakala et al., 2011), corporate brand identities (Urde et al., 2007: Wiedmann et al., 2011a) and corporate identities too (Balmer 2011b). Heritage is seen to be relevant for organisations of varying size and hue and, as such, encompasses multinational enterprises along with small, family-run, businesses (Micelotta and Raynard, 2011).

The importance of brand heritage has been scrutinised along a number of dimensions. For instance, it has been discussed as an important source of brand authenticity (Beverland, 2005, 2006); can imbue a brand with a particular "aura" (Alexander, 2009); is of especial relevance for luxury brands (Moore 
and Birtwistle, 2005; Beverland, 2006; Fionda and Moore, 2009) and can be materially significant in terms of culturally anchored, so called "iconic", brands (Alexander, 2009; see Holt, 2004).

In consumer and services marketing contexts, heritage has, over years, attracted the attention of a number of scholars (Liebrenz-Himes et al., 2007; Banerjee, 2008; Hakala et al., 2011). For instance, heritage is seen to be an important driver of customer value (Wiedmann et al., 2011a). Heritage is also seen to be relevant in experiential and emotional terms in consumer and service marketing contexts (Peñaloza, 2000; Ponsonby-Mccabe and Boyle, 2006). Moreover, heritage may significantly contribute to consumers' emotional and symbolic attachment to a brand (Ballantyne et al., 2006).

In more general instrumental terms, heritage has been articulated in the context of planned "heritage communication" (Bühler and Dürig, 2008).

However, heritage is sometimes conceptualised in somewhat loose terms within the corporate marketing and management canons and, moreover, among marketing managers and practitioners. For instance, whilst Urde et al. (2007) point out that heritage is significantly different from history, there is anecdotal evidence that many companies now refer to their "heritage" when they talk about the organisation's "history" in corporate communications. In part, this might represent a pragmatic reaction by businesses and other organisations to socio-cultural sentiments within society that tend to valorise different forms of cultural and natural heritage (Isar, Viejo-Rose and Anheier, 2011; McDonald, 2011) as a cultural resource for consumption purposes (Goulding, 2000, 2001) but also as a marker of individual and collective identities at different levels (Graham and Howard, 2008). Moreover, the growing reference to heritage may, perhaps, partially reflect the inflationary use of the term in academic and vernacular discourses within society in general (Samuel, 1996; Lowenthal, 1998). In the light of the above, the theoretical and instrumental elaboration of heritage is warranted and heritage represents a potentially fruitful conceptual lense for marketing and corporate marketing scholarship (Balmer, 2011b).

\section{Corporate heritage dimensions}

Uncovering the characteristics of corporate heritage is one of the key academic concerns and themes to emerge from the literature. As such, marketing scholars have variously examined the dimensions of 
corporate heritage brands (Urde et al., 2007; Balmer, 2011a; Hudson, 2011; Wiedmann et al., 2011a, 2011b) and, more recently, in the context of corporate heritage identities (Balmer, 2011b). To reiterate, corporate heritage brand identities and corporate heritage identities are viewed as distinct - albeit related - identity types (Balmer, 2011a, 2011b, 2013).

To reprise an earlier point, this study focuses on corporate heritage identities along with their specific management requirements. Corporate identity represents the much broader and more fundamental concept (Balmer 2008).

In delineating the nature of corporate heritage, the extant literature makes a distinction between heritage and history. Thus, while all organisations have a past with a particular historical trajectory, some organisation it has been suggested "possess" a unique corporate heritage that becomes central for their corporate identities linking an organisation's past with the present and an envisioned future in a meaningful way; potentially being leveraged as a strategic resource for corporate-level marketing in terms of positioning corporate brands (Urde et al., 2007) and corporate identities in addition (Balmer, 2011a, Balmer, 2011b).

To date, the framework by Urde et al. (2007) - the corporate heritage brand quotient - and subsequent discussions of the concept (Balmer, 2011a, 2011b) detail both identity and instrumental characteristics of corporate heritage brands and identities, which refer to characteristics in terms of their: (1) temporality; (2) continuity; (3) relative invariance; and (4) role identity multiplicity: see table 1.

Due to the distinct conceptual characteristics identified in the extant literature and deliberated on above it has been argued that corporate heritage identities and brands need to be managed in a particular way, viz. corporate heritage stewardship (Urde et al., 2007; Balmer, 2011a, 2011b, 2013).

\section{INSERT TABLE 1 AROUND HERE}

\section{Corporate heritage stewardship}

To account for the specific management requirements of corporate heritage identities and brands the notion of corporate heritage brand stewardship was introduced by Urde et al. (2007), which is 


\section{$28^{\text {th }}$ February, 2014}

predicated on a particular "management mind-set of nurturing, maintaining, and protecting brand heritage" (Urde et al., 2007, p. 9).

According to Urde et al. (2007) the management stewardship of heritage in an institutional context and its utilisation as a strategic corporate marketing asset entails on the one hand the active "uncovering" of heritage that may even lead to the discovery or re-discovery of a hitherto hidden heritage (Urde et al., 2007) and the activation or re-activation of the prior discovered or re-discovered institutional heritage for corporate-level marketing purposes (Urde et al., 2007). On the other hand, it also requires the custodianship of senior management, particularly the CEO, which is concerned with "protecting" the institutional heritage that is part of the corporate brand or identity (Urde et al., 2007). Hence, heritage stewardship is based on the marriage of retrospective brand archaeology, which is a managerial "concern with a brand's provenance and historic attractiveness" (Balmer, 2011a, p. 4) and of prospective brand strategy that involves "marshalling the brand heritage in order to maintain its brand saliency and competitive advantage for the future" (Balmer, 2011a, p. 4).

The notion of stewardship combines in a way the cerebral aspects of understanding and interpretation with the practical dimension of doing and acting (Balmer, 2008) and accords importance to management in regard to the particular enactment of corporate heritage brands and identities; stewardship being at once instrumental and constitutive. In more theoretical terms, management perceptions and selfunderstanding of their organisation's identity have been found to be an important dimension of corporate identity strategy enactment (He and Balmer, 2007; 2013; He, 2012). Such a perspective has long-informed instrumental insights relating to the corporate identity and corporate brand identity domains as per the ACID Test diagnostic framework (Balmer and Greyser, 2003; Balmer et al., 2009; Balmer, 2012).

As such, heritage stewardship is fundamentally predicated on a particular managerial mind-set - a general understanding, orientation, and disposition to act in terms of the nature and role of a corporate brand and identity - that is comprised of two main aspects.

The first aspect is a focus on long-term continuity, which also entails adaptability and a dedication to continuous improvement. The second aspect refers to a trans-generational sense of responsibility for the brand/identity and its heritage. 
Both are said to be instrumental for safeguarding the brand's relevance, credibility and trust $v i s-\grave{a}-$ vis its various stakeholders and in the light of changing demands and conditions over time (Urde et al., 2007), thus maintaining the saliency of the corporate heritage brand/identity (Balmer, 2011a, 2011b).

\section{Rationale for the study}

As our review of this nascent field indicates, the constitutive dimensions and characteristics of corporate heritage brands and identities and their relevance for stakeholders (e.g. customers) have attracted recent scholarly interest (e.g. Balmer, 2011a, 2011b; Hudson, 2011; Wiedmann et al., 2011a, 2011b). However, the field is still in its infancy. Conceptual, and more specifically empirical work on the domain, are slight. As with any new domain, there is, sometimes, inconsistency in how corporate heritage and analogous constructs are defined. To date, the majority of extant work is predominately conceptual and tentative in nature, with the more empirical work providing rich descriptive insights on the domain - but not so much in terms of theoretical insights - focusing on well-known brands and organisations. In light of the above, and noting the importance accorded to corporate heritage stewardship, it is evident that empirical research on the aforementioned would meaningfully advance extant conceptual contributions.

Developing the above, corporate heritage stewardship and the particular managerial mindset required for the management of these distinct types of institutional brands/identities has so far received little further empirical scrutiny - and theoretical advance - outside the concept's original domain of monarchies as corporate brands and heritage institutions (see Balmer, 2011a) and the research contributing to its original articulation by Urde et al. (2007).

Taking a broader vista, the corporate marketing literature has focused on the role of management perceptions in the context of corporate identities (He and Balmer, 2007b, 2013; He, 2012), the nature of corporate brand strategy enactment (Vallaster and de Chernatony, 2005, 2006; Vallaster and Lindgreen, 2011) and the normative role of CEOs/the top management team in general (Balmer, 1995,2009b, 2012b; Balmer and Greyser, 2003) but not yet scrutinised corporate heritage identities/brands as such. 


\section{$28^{\text {th }}$ February, 2014}

Similarly, within the academic domain of management, stewardship theory has been conceptually discussed as an alternative approach to corporate governance, which is underpinned by particular situational and psychological factors that facilitate stewardship behaviour amongst managers or employees (Davis et al., 1997; Hernandez, 2012) but has not yet provided sufficient empirical evidence of institutionalised forms of management stewardship characteristic for particular types of organisations especially in the private sector (Segal and Lehrer, 2012).

Therefore, the focus of this study is to address a gap in the extant literature in relation to corporate heritage identity management in particular and, moreover, to make a theoretical contribution relating to the nature of managerial corporate heritage identity stewardship. In particular, this research focusses on the different dimensions that constitute the managerial mindset/self-understanding necessary for the successful management of corporate heritage identities within a business context.

To reiterate, this empirical theory building study makes a contribution, in theoretical terms, to the nascent corporate heritage field by revealing key interpretative dimensions pertaining to corporate heritage identity stewardship as understood by managers.

Research insights from this study underpin the theory of corporate heritage identity stewardship in the form of a theoretical framework. The research findings also provided instrumental insights by uncovering salient traits in regard to corporate heritage identity stewardship.

\section{Shepherd Neame: context and company background}

Unlike extant studies either within corporate marketing in general that tend to focus on large multinational enterprises (Abimbola and Kocak, 2007) or in the nascent area of corporate heritage brands and identities in particular, which have focused so far on well-known business and non-business organisations and brands (e.g. Urde et al., 2007; Balmer, 2011a, 2011b; Hudson, 2011), the current study is situated within the empirical context of the UK's oldest brewery, viz. Shepherd Neame: a regional multi-generational family-owned company based in the Southeast of the UK.

Multi-generational family-owned companies of considerable maturity are largely under-researched in general (Micelotta and Raynard, 2011) but have been suggested, understandably, as a focus of empirical research relevant for our understanding of corporate heritage in regard to corporate identities 
in particular (Balmer et al., 2006; Blombäck and Brunninge, 2009). Furthermore, regional and familyowned companies may have a utility in shedding light on management stewardship in general (Segal and Lehrer, 2012).

In more general terms, the notion of corporate heritage as a strategic resource for corporate branding strategies has recently attracted attention from a family business perspective (Micelotta and Raynard, 2011). However, this research has largely focused on the strategic relevance of the familial dimension for corporate identities/brands (Craig et al., 2008) rather than corporate heritage identities and their management in a family business context as such, despite the prima facie salience of family-businesses of considerable maturity that could qualify - following Urde et al. (2007) - as corporate heritage identities/brands.

The case study focuses on the UK brewing sector, which is significant within the UK in terms of annual turnover, tax contributions, employment, and cultural relevance (Sheen, 2011; Muir, 2012; Oxford Economics, 2012). The industry is also characterised by a high level of competitive dynamic and change, government regulation as well as societal scrutiny and interest (Knowles and Egan, 2002; see Pratten, 2007a, 2007b, 2007c), thus, representing an interesting backdrop for corporate marketing issues in general. Further, within the brewing industry as one of the oldest industries in the UK (Mathias, 1959; Gourvish and Wilson, 1994), despite the market being dominated by large multi-national corporations, there are a significant number of multi-generational and long-established companies still operating within that industry. This case study focuses on the oldest of these. In addition, the sector constitutes a relevant empirical domain for heritage-based corporate marketing and past-related consumer marketing activities (e.g. Blombäck and Brunninge, 2009; Byrom and Lehman, 2009; Alexander, 2009).

Apart from its instrumental relevance for the theoretical elaboration of corporate heritage stewardship the case study itself is significant in that its focus is on Britain's oldest brewer: Shepherd Neame. Established in 1698, it is one of the UK's oldest operational commercial enterprises: see table 2 (which provides a company overview).

INSERT TABLE 2 AROUND HERE 


\section{Research method}

In light of the theory building purpose of the study, a single in-depth case design broadly situated within the interpretative, qualitative research tradition underpinned by moderate constructionist convictions informs this empirical study (Blaikie, 2007, 2009). This approach is appropriate for theory building case research where extant empirical research is limited and where an insight into an organisational phenomenon such as corporate heritage stewardship is slight (Eisenhardt, 1989; Yin, 2009). Moreover, qualitative case study research enables a prolonged hermeneutic interaction between empirical data, emerging conceptual framework, and extant literature (Corbin and Strauss, 2008).

We broadly followed the conventions of a holistic single case study design (Yin, 2009) with our empirical case being taken as representative or typical for a corporate heritage identity without subscribing to the positivist stance/replication logic expounded by Yin (2009) or Eisenhardt (1989) that subsequently would undermine the theoretical and empirical relevance of a single-case design.

Within a non-positivist framework case-based research facilitates the convergence of the empirical emic dimension with the conceptual etic dimension of a social phenomenon (Walton, 1992; Harper, 1992).

As such, our main focus was on its instrumental relevance for understanding, in theoretical terms, the abstract concept of corporate heritage identity stewardship rather than on articulating unique and intrinsic characteristics of the case per se (Stake, 1995), which is nonetheless illustrative of the phenomenon (Siggelkow, 2007).

A case study based research design is well suited for generating particularistic as well as holistic forms of knowledge (Hamel, 1992; Verschuren, 2003; Stake, 2005) and where a close interaction between researcher and social setting is required for exploring and understanding a focal phenomenon of interest in its manifold manifestations (Gummesson, 2000). As such, the case study approach differs from experimental as well as survey-based approaches to social inquiry with the former relying on theoretical inference under controlled conditions and the latter aiming for statistical generalisation to a larger population (Hammersley and Gomm, 2000; Yin, 2009) 


\section{$28^{\text {th }}$ February, 2014}

Consequently, we do not attempt to derive at statistical/substantive generalisations across different empirical instances/domains, but to understand the properties of the construct of corporate heritage identity and its particular stewardship requirements/characteristics based on an exemplary empirical case that is also "revelatory" in nature (Yin, 2009) taking place within Britain's oldest brewer. Thus, it is representing an indicative "blueprint" of the concept at a higher level of abstraction to be refined, further specified and subsequently, if only partially, transferred to other empirical contexts by future research (Blaikie, 2009) taking into account the situated and theory-laden nature of all knowledge claims (Sayer, 1992).

Case studies represent an established approach within the methodological canon of corporate marketing research (e.g. Balmer, 1996; Balmer and Stotvig, 1997; Balmer and Wilson, 1998; Andriopoulos and Gotsi, 2001; Motion, Leitch and Brodie, 2003; He, 2004; Powell, 2005; Melewar and Akel, 2005; Bendixen and Abratt, 2007; Maxwell and Knox, 2009; Leitch and Davenport, 2011; Simões and Mason, 2012).

Consistent with our moderate constructionist paradigmatic convictions and mindful of the research approach outlined above, the resultant theory emerging from this empirical study is, following on from (Charmaz, 2006), classified as an interpretative theory. Interpretative theories advance knowledge by providing understanding and illumination. Moreover, this often results in an abstraction of lay concepts into academic ones and, as such, this constitutes indicative social scientific typifications (Schütz, 1962).

Interpretive theories assume emergence, situatedness, non-linear relations, and a large degree of indeterminacy (Charmaz, 2006).

Importantly, an interpretative theory, including the resultant theory emerging from this study, does not aim and yield deterministic explanations or formulates causal linear relationships between variables (Charmaz, 2006). This has a bearing on diagrammatic depictions of interpretative theories. As such, there needs to be mindfulness that graphic depictions of an interpretative theoretical framework, typically, are an abstract-analytic rather than an empirical-causal form. This implies that interpretative theoretical frameworks highlight patterns and arrangements to a more heightened degree than frameworks informed by positivistic theories where specific directional relationships between variables is the modus operandi (Turner, 1987 cited in Blaikie, 2009, p. 152) 


\section{$28^{\text {th }}$ February, 2014}

Based on an initial review of the literature some broad preliminary concepts (Yin, 2009) were used in a sensitising mode (Blumer, 1969). These concepts helped to situate the study in its disciplinary and theoretical context that informed and guided the selection of the case itself, the identification of relevant units of analysis and indicated towards likely types and sources of data (Yin, 2009).

After identifying and considering a number of sectors, based on several criteria such as maturity of the industry and the level of current activity in the UK, it was decided to focus on the brewing sector. After contacting those breweries - and following the work of Urde et al. (2007) - which prima facie conformed to being highly relevant in terms of the corporate heritage identity construct access was granted to two breweries.

Following general recommendation within the precepts of case study research (Yin, 2009) seven pilot interviews were conducted and a limited number of documents were collected at one of the breweries in order to assess and "fine-tune" the research design and to test techniques and tools (e.g. software package for data analysis). The other brewery was selected as main case company - apart from its professed status as Britain's oldest brewer - due to the level of access granted, the existence of a company archive and the company's active use of heritage themes in their corporate-level marketing activities.

Nineteen open and semi-structured interviews (a total of approx. 20 hours of interviews) with a cross-section of directors (5) and managers (9) were conducted as part of the main study. These interviews lasted between 45 to 95 minutes, of which fourteen were formally audio recorded (approx. 16.5 hours of interviews) and subsequently transcribed by a third party, while mental notes were taken during the interviews where recording was not possible (some interviews were not recorded due to the particular interview setting; for instance an interview conducted while having lunch with a director). The transcribed interviews yielded about 170,000 words of textual data. Table 3 provides an overview of the interviews conducted.

\section{INSERT TABLE 3 AROUND HERE}


Additionally, textual documents were inspected and analysed such as corporate communication reports, strategy documents, annual reports, in house and customer magazines, historical archived materials, along with documents in the public domain (e.g. company website, trade and business press). Further, visual data were collected and a limited number of non-participant observations took place during the project (e.g. during site visits, guided tours, beer festivals, personal pub and hotel visits). Such a broad variety of different additional textual and visual data was collected in order to enable triangulation of the data in accordance with the precepts of case study research (Yin 2009). In addition, we perceived textual documents as cultural artefacts that reveal much about the identity and heritage claims made about the organisation (Chreim, 2005) potentially revealing important aspects of management stewardship especially in the context of corporate marketing.

The generated data were examined and analysed - broadly following an abductive research logic (Blaikie, 2009) and the precepts of grounded analysis (Easterby-Smith, Thorpe and Jackson, 2008) through a multi-stage coding process facilitated by software (MaxQDA 10), which is recommended for qualitative and interpretative research of this kind (Corbin and Strauss, 2008). Data analysis and synthesis was carried out as an iterative and cyclical process facilitated by reflective memo writing and conceptual mapping and a prolonged hermeneutic interaction between empirical data, emerging framework, and extant theory (Corbin and Strauss, 2008). Figure 1 schematically depicts the analytic process.

\section{INSERT FIGURE 1 AROUND HERE}

The coding process of interview data yielded 759 open codes that were relationally integrated into 14 selective codes. Gradually, six main categories emerged from the process, which were corroborated by qualitative triangulation (Flick, 1992, 2007) based on the thematic analysis of other textual and observational data in order to specify and contextualise these categories (see figure 2). Hence, the salience of the heritage stewardship theme for our study did actually emerge from the data and the interplay with several sensitising concepts in order to make sense of the data and was not a priori chosen as a central interpretative frame, which the conventional structure of a journal article may imply. As a 
result of the prolonged interpretative process the six categories were further synthesised into three main dimensions and both integrated into a theoretical framework.

\section{INSERT FIGURE 2 AROUND HERE}

\section{Findings}

Our analysis and synthesis of the empirical data suggest a close relationship between the particular manifestation of the case company's corporate heritage identity and a specific multi-faceted mindset shared amongst the management team of the organisation. We found this to be constitutive and instrumental for the strategic enactment of the corporate heritage identity in terms of its implementation and positioning vis-à-vis the company's stakeholders and within its various societal environments. We suggest a theoretical framework explicating the different aspects of the substantive Corporate Heritage Identity Stewardship (CHIS) theory that emerged from our study. Within the theoretical framework, which articulates the substantive theory in conceptual terms, the CHIS mindset conceptually comprises six managerial dispositions (CHIS dispositions) to feel, think, and act that manifest in three broader managerial awareness dimensions (CHIS awareness dimensions) expressed by managers: see table 4 .

\section{INSERT TABLE 4 AROUND HERE}

Together, the three CHIS awareness dimensions and the associated six CHIS dispositions constitute the CHIS mindset. It articulates at once a shared managerial sentiment (affective), an understanding (cognitive), and a propensity (performative) towards the organisation and its institutional heritage itself (e.g. its position, role and purpose) as well as in regard to the organisation in relation to various stakeholders and the societal environments within which the company is embedded and has acquired a heritage status. Thus, the six managerial CHIS dispositions that underpin the three broad CHIS awareness dimensions are descriptively labelled "senses" in order to indicate their tripartite character of being at once a managerial sentiment, an understanding, and a propensity to act towards and on behalf of the organisation. 


\section{$28^{\text {th }}$ February, 2014}

Within our theoretical framework the thus specified CHIS mindset is constitutive and instrumental for the strategic enactment of a corporate identity as a corporate heritage identity by managers guiding corporate marketing activities.

We explicate each of the identified CHIS awareness dimensions and their associated CHIS dispositions in the following sections before we integrate our findings into a conceptual framework of an emerging corporate heritage identity stewardship theory. Illustrative interview quotes and additional illustrative evidence are provided in the appendix.

The presented quotes are illustrative for a general pattern that emerged from the interviews but was also found to be salient for the particular ways in which the corporate heritage identity of the firm is strategically enacted and represented to the company's stakeholders. Thus, the interpretative dimensions were corroborated by manifestations thereof such as policies, practices, strategies etc.

For confidentiality reasons and due to the relative small size of the case organisation we do not disclose the name or position of any individual interviewed in conjunction with a quote and refer only to the generic labels of director and manager.

\section{Positionality Awareness}

This CHIS awareness dimension, Positionality Awareness, expressed by managers refers to a managerial awareness in regard to the company's particular socio-historical position within its societal environments, in terms of a relation to past, present and future (temporal); in relation to a place and location (spatial), and in relation to the identities of individual and collective stakeholders (sociocultural). This CHIS awareness dimension expressed by managers is characterised by and derived from three interrelated CHIS dispositions: Sense of Continuance, Sense of Belongingness, and Sense of Self.

\section{Sense of Continuance}

This CHIS disposition, Sense of Continuance, refers to management's expressed concern for and awareness of the company's long persistence over time: it has so far and should also in future prevail 
as an institution. On the one hand it is related to a managerial focus on continuity expressed by managers as four different forms of continuity: temporal, institutional, spatial, and social. On the other hand, this disposition is characterised by a professed long-term orientation towards the business (i.e. focus on the long-term) paired with a focus on adaptation in terms of the necessity, ability, and willingness to adapt to changing circumstances in order for the company to prevail long-term. All three managerial foci are interrelated and as such concur into the particular CHIS disposition Sense of Continuance (see appendix exhibit 1 for illustrative quotes/evidence).

\section{Sense of Belongingness}

This managerial CHIS disposition, Sense of Belongingness, stresses the importance of attachment, affiliation, and affinity towards place (e.g. home town and county), social groups, and institutions (e.g. family, community, industry) for the enactment of the corporate identity, which was found to be predicated on aspects of closeness (proximity) and provenance (origin). Hence, it refers to questions such as "where do we come from," "where do we belong to," or "who or what are we close to." As such, the dimension of belongingness often concurs with the notion of continuance but has a more emotive/affective connotation. It reflects a "strong sense of belonging" that manifests itself in the company's identity, policies, and strategies.

The aspect of focus on closeness refers to the professed spatial and socio-cultural proximity between the company and any of the aforementioned social groups or institutions (e.g. family, community, industry), while the concurrent dimension focus on provenance relates to the notion of spatial, sociocultural origin and is as such closely coupled with former. The Sense of Belongingness disposition was manifested in different ways (see appendix exhibit 2 for illustrative quotes/evidence).

\section{Sense of self}

This CHIS disposition, Sense of Self, refers to non-conformist disposition shared amongst managers that is constituted by two interrelated aspects: independence and individuality. It refers to a managerial 
appreciation of affective, cognitive, and performative independence and individuality in regard to corporate strategy, direction, and conduct. This aspect imbues management feeling, thinking, and acting with a strong sense of confidence towards a perceived non-conformism in regard to strategies and policies pursued. The managerial focus on independence relates to the concept of autonomy, while the focus on individuality connotes the notion of difference and plurality in feeling, thinking, and acting. Both aspects closely interact in that autonomy justifies difference and the latter reinforces the former (see appendix exhibit 4 for illustrative quotes/evidence).

\section{Heritage Awareness/Sense of Heritage}

The CHIS awareness dimension Heritage Awareness refers to a managerial understanding of the company's particular status as an organisation with an institutional corporate heritage that represents a shared inheritance, which is worth to be protected, nurtured, and bequeathed to the next generation. It is based on the CHIS disposition Sense of Heritage. This managerial disposition refers to the managerial validation (acknowledging), appreciation (valuing), and adoption (ownership taking) of the company's institutional corporate heritage and of the company's heritage status within its societal and institutional environments, which are perceived as strategically efficacious for the present and the future of the company (see appendix exhibit 4 for illustrative quotes/evidence).

\section{Custodianship Awareness}

This CHIS awareness dimension, Custodianship Awareness, expressed by managers refers to a managerial awareness of a shared custodial obligation and duty to speak and act for the company and on behalf of others in an authorial way, which is perceived as legitimate by management due to their concurrent understanding of the company's status as an organisation imbued with an institutional heritage (i.e. Heritage Awareness) and its particular socio-historical position (i.e. Positionality Awareness). It is constituted by two interdependent CHIS dispositions articulated by managers: Sense of Responsibility and Sense of Potency. 
Custodianship Awareness is characterised by the CHIS disposition Sense of Responsibility, which is constituted by two aspects: institutional custodianship and non-institutional custodianship. The former stresses a managerially perceived custodial obligation towards the organisation and its institutional heritage that is derived from the instrumental necessity to protect, nurture, and bequeath the corporate heritage (and the company), which implies intergenerational exchange between present and future generations. The latter aspect indicates a professed sense of custodial duty that goes beyond the company and its corporate heritage itself predicated on the perceived heritage status of the organisation justifying and demanding such an expanded notion of responsibility (see appendix exhibit 5 for illustrative quotes/evidence).

\section{Sense of Potency}

The CHIS Disposition Sense of Potency closely interacts with the above discussed sense of responsibility. However, it carries the notion of perceived legitimacy rather than obligation and duty. It imbues the company and its management with a "license to speak and act" partially justified by the heritage status of the firm, which implies (claimed) authenticity, credibility, and legitimacy vis-à-vis the company's stakeholders. Thus, it denominates a clear understanding of corporate purpose and corporate authority expressed by managers in terms of communicative action in regard to immediate institutional concerns but also issues beyond the organisation itself, which is facilitated by the company's heritage status (see appendix exhibit 6 for illustrative quotes/evidence).

\section{Theoretical framework}

The Corporate Heritage Identity Stewardship Theory explains that the specific enactment of a corporate heritage identity is predicated on a particular, albeit multi-faceted, management mind-set. The theoretical framework integrates the different building blocks outlined above. Figure 3 schematically depicts the theoretical framework of the Corporate Heritage Identity Stewardship Theory constitutive and instrumental for the strategic enactment of corporate heritage identities. 
Conceptually, the six different managerial CHIS dispositions interact and this accounts for the three, broad, CHIS awareness dimensions. These, interdependently, constitute a collective CHIS management mind-set. They are mutually reinforcing.

To recapitulate, the CHIS mind-set variously articulates a shared managerial sentiment; a common management understanding, and a collective managerial propensity towards the organisation and its institutional heritage, stakeholders, and the societal environments within which the company is embedded and from which it has attained its especial heritage status.

Consequently, the relationships between the conceptual building blocks of the theoretical framework are non-linear, bi-directional, and emergent in nature. To reiterate, our theoretical framework is based on an interpretative type of theory and as such illuminates - despite the indicative use of arrows in its graphic depiction (see figure 3) - emergent patterns and non-linear relations between concepts in a holistic fashion (Charmaz, 2006). The aim is not, as in positivistic models, to provide a deterministic explanation of tightly specified causal linear relationships between variables as noted by Charmaz (2006).

\section{INSERT FIGURE 3 AROUND HERE}

In particular, we argue that a managerial Sense of Continuance interacts with a professed Sense of Belongingness and a profound Sense of Self, which all coalesce into a managerial awareness of the specific socio-historical position of the organisation: Positionality Awareness (section "Our temporal, spatial, and socio-cultural place in the world" in figure 3).

The first disposition Sense of Continuance is characterised by a long-term orientation and view of the business paired with a concurrent focus on continuity and adaptation, while the second disposition of Sense of Belongingness refers to the general importance accorded to the company's attachment, affiliation, and affinity towards place, social groups and/or institutions in terms of its spatial and/or socio-cultural closeness (proximity) and its spatial and/or socio-cultural provenance (origin). The third disposition Sense of Self interacts with both and articulates the importance accorded by managers to non-conformist independence and individuality in terms of corporate policies and strategies. Through 
the interaction (indicated by the bi-directional arrows) of these three dispositions a shared managerial understanding emerges (indicated by the shaded area in the model) in regard to the company's temporal, spatial, and socio-cultural place in the word.

Further, we suggest that the above articulated awareness of the company's specific temporal, spatial, and socio-cultural position within its various environments (e.g. economic, socio-cultural, institutional) concurs with a shared managerial understanding of the company as an organisation imbued with a valuable and relevant institutional heritage (i.e. corporate heritage) having acquired a particular status within those environments (i.e. heritage status). As such, this managerial Heritage Awareness (section "Our inheritance that is still relevant and worth to be protected, nurtured and bequeathed" in figure 3) emerges from (indicated by the shaded area in the model), is underpinned by, the fourth disposition labelled Sense of Heritage, which is characterised by the validation (acknowledging), appreciation (valuing), and adoption (ownership taking) of the institutional heritage itself (i.e. corporate identity traits perceived as substantive heritage dimensions) and the company's particular status as an organisation imbued with that heritage. At the same time the institutional heritage and the company's heritage status are perceived by managers not only as a legacy to be honoured but as being relevant for the present and future of the company, hence, they are still invested with new instrumental value (i.e. valorised) and appropriated for corporate marketing purposes.

Due to the interaction (indicated by the bi-directional arrow in the model) between the above described CHIS awareness dimensions of Positionality Awareness and Heritage Awareness we further purport that a third managerial CHIS awareness dimension emerges, viz. Custodianship Awareness (indicated by the two unidirectional arrows and the shaded area in the model). It is constituted by the interrelation (indicated by the bi-directional arrows) between a Sense of Responsibility indicating connotations of obligation and duty and a Sense of Potency carrying an association with authenticity, legitimacy, and credibility (section "Our obligation and licence to speak and act for us and others in a custodial role." in figure 3).

The fifth disposition Sense of Responsibility indicates a perceived custodial obligation in regard to the company and its institutional heritage, while the perceived company's heritage status warrants an expanded notion of responsibility (i.e. duty) and entails a professed custodial role beyond the boundaries 


\section{$28^{\text {th }}$ February, 2014}

of the firm itself. The final disposition Sense of Potency refers to a shared sense of purpose and authority. It imbues the company and its management with a "license to speak and act" based on and justified by the heritage status of the firm, which implies (claimed) authenticity, credibility, and legitimacy in relation to the company's stakeholders.

The three CHIS awareness dimensions deduced from the study (i.e. Positionality Awareness, Heritage Awareness, Custodianship Awareness) are mutually constitutive and reinforcing. Thus, the Heritage Awareness interacts with a shared understanding of the company's particular socio-historical position: Positionality Awareness. Both provide the obligating and legitimating underpinning for the notion of custodianship fashioned by managers (i.e. Custodianship Awareness), which in turn reinforces the managerial self-understanding in regard to the former two awareness dimensions (indicated by the two dotted unidirectional arrow in the model).

Finally, we argue that the interaction between the three CHIS awareness dimensions results in a shared managerial CHIS mindset informing the corporate heritage identity stewardship activities of management (i.e. managerial and strategic action), which are constitutive for and have instrumental necessity for the strategic enactment of the corporate heritage identity vis-à-vis stakeholders and within multiple societal environments (indicated by the large arrow in the model).

\section{Discussion}

The empirical evidence underpinning the CHIS disposition sense of continuance largely confirms the focus on long-term continuity predicated on adaptability and a striving for continuous improvement suggested by Urde et al. (2007) as an important dimension of corporate heritage stewardship. However, the sense of continuance conceptualised as the result of this study is more elaborate and expansive in that it provides a specified and more detailed account of the notion of focus on continuity (i.e. temporal, spatial, institutional, social) showing its multi-dimensional characteristics. Further, the focus on the long-term continuity of an organisation in general as identified by Balmer et al., (2006) and Urde et al. (2007) - the current findings indicate - is accompanied by a general long-term view of doing business, which represents a specific managerial frame of reference for strategic decision making expressed by managers. Thus, it is not only a focus on the continuity of the institution (and its corporate identity or 


\section{$28^{\text {th }}$ February, 2014}

its corporate brand) manifested in concerns for institutional arrangements and a core business model/industry affiliation that is an important dimension of a corporate heritage identity stewardship mindset but also the continuity of stakeholder relations within and beyond the company and the continuity of place and location that guide managerial understanding and action. Hence, the study has shown that the focus on continuity is facilitated by a necessary long-term temporal orientation and outlook that manager's share, which is of strategic significance as much as a central dimensions of managerial self-understanding and seen as an important trait of the company's identity in comparison to other more short-term oriented businesses.

The equal importance accorded to continuity and change that was found to be present amongst managers confirms a conceptual tenet recently articulated by Balmer (2011a), which states that corporate heritage identities need to concurrently embrace continuity and change in order to stay meaningful and salient (Balmer, 2011b); a managerial sentiment empirically identified by Hudson (2011) as well. In addition, the current study's findings indicate also that there is a managerial appreciation for the need to balance the long-term orientation with short-term pressures to satisfy stakeholder expectations in the present while staying true to past and future concerns.

The CHIS disposition Sense of Belongingness indirectly provides support for the notion of reciprocity advanced by Balmer (2011a, 2011b) in regard to trust as a fundamental aspect of corporate heritage brand/identity saliency. However, the findings of the study indicate that the associated affinity dimension of that saliency (see Balmer, 2011a; 2011b) is equally reciprocal in that the notion of belongingness is not confined to the identification of various stakeholders with the firm but also based on the importance accorded to attachment, affiliation, and affinity towards place, social groups, and institutions by management and manifested in the strategic corporate heritage identity enactment (e.g. spatial and socio-cultural anchoring) supporting the earlier mentioned notion of meaningful bilateral relationships that characterise corporate heritage brands/identities (Balmer, 2011a, 2011b). It further supports the notion of corporate heritage identities being partially constituted in relation to the cultural heritage and the identities of other societal entities and actors imbuing it with cultural relevance and legitimacy (Balmer, 2011b; also see Foster et al., 2011). Moreover, it lends support to the notion of brand archaeology as a concern with provenance and historic attractiveness (Balmer, 2011b). However, 


\section{$28^{\text {th }}$ February, 2014}

the identified Sense of Belongingness is more expansive in regard to being concurrently concerned with spatial and socio-cultural proximity and origin, which provides indirect evidence for the potentially much broader base for the organisation's legitimacy and stakeholder relevance suggested by Balmer (Balmer, 2011b). Indirect support for the relevance of belongingness is provided by the study undertaken by Wiedmann and colleagues (Wiedmann et al., 2011a, 2011b) who found 'bonding' to be the most important driver of heritage value for customers.

Further, the findings support the notion of a trans-generational sense of responsibility discussed by Urde et al. (2007) and the strategic aspects of marshalling corporate heritage identified by Balmer (2011a) as a core dimension of management stewardship. However, the study provides further evidence for the interdependence between the notion of responsibility and a sense of continuance as well as the managerial disposition labelled Sense of Belongingness. More importantly, the claimed/perceived heritage status of the corporate identity informs not only the custodial role for the institutional heritage but also legitimates (for managers) a sense of responsibility beyond the company itself. This more expansive notion of responsibility in conjunction with the Sense of Belongingness expressed by managers and manifested in the strategic enactment of the corporate heritage identity lends further support to the notion of corporate heritage identities being partially constituted in relation to the cultural heritage of other social entities (e.g. Kent/UK brewing heritage, hop growing heritage, pub heritage) legitimating the corporate heritage identity within a wider socio-cultural context (Balmer, 2011b) as well as for a corporate heritage identity having acquired different institutional roles over time (Balmer, 2011b).

The notion of potency (i.e. CHIS disposition Sense of Potency) supports the strategic and proactive aspects of corporate heritage stewardship in regard to the activation of corporate heritage for corporate marketing purposes (Urde et al., 2007). The findings further support, at least in the way it is envisaged by management, the reciprocal dimension of trust and affinity mentioned above, which is predicated on the activation of corporate heritage as a stable point of reference for stakeholder identification and a base for the organisation's legitimacy (Balmer, 2011b). As such, the 'traditional authority' of a corporate heritage identity is predicated on its temporal transcendence as much as its cultural relevance 
(Balmer, 2011b). The study also shows that the heritage status of the organisation helps to selfauthenticate and self-legitimise managerial agency in relation to stakeholders (He and Balmer, 2007b).

Thus, custodianship awareness identified as a core awareness dimension shared by managers is concurrently characterised by a perceived obligation and duty towards the organisation and the societal environs within it operates as well as a perceived legitimacy and credibility to act in that custodial role for self and others. This notion of custodianship goes beyond the extant discussion in the corporate heritage literature with a focus on custodianship for the institution and its brand/identity (Urde et al., 2007; Balmer, 2009b; 2011b).

Further, the study revealed that a CHIS mindset is also characterised by a managerial Sense of Heritage per se with management validating, appreciating, and adopting the corporate heritage and the organisation's heritage status vis-à-vis stakeholders and within societal environments. This disposition supports the general notion of the importance accorded to history by managers as an important aspect of identity (Urde et al., 2007). However, it is more specific in that it exhibits a relational and positional dimension in terms of the importance of the heritage status of the organisation in relation to its stakeholders and within its various societal environments. Moreover, the dimensions of validation, appreciation, and adoption expand the managerial dimensions of uncovering, activating, and protecting the corporate heritage brand/identity (Urde at al., 2007), which were broadly confirmed by the current study (e.g. the dedicated role of the company archivist to uncover the company's past in order to be activated in a corporate marketing context). As such, the study suggests that a CHIS mindset involves 'taking ownership' of the corporate heritage as well.

The above was found to be partially predicated on the close link between corporate identity characteristics in general and corporate heritage traits expressed by managers and strategically enacted as part of the corporate identity, which provides empirical support for the notion of a macro-level heritage footprint recently advanced by Balmer (2011b). Moreover, the substantive corporate heritage identity traits referred to by managers are company-specific and as such complementary to the generic corporate heritage characteristics expressed by the heritage quotient framework suggested by Urde et al. (2007). 
Finally, the CHIS mindset exhibits a strong managerial sense of self-facilitating autonomy and individuality in terms of feeling, thinking an acting (i.e. Sense of Self), which is partially predicated on the heritage status of the organisation and its particular socio-historical position. This aspect further expands the extant stewardship conceptualisation discussed in the literature by adding a new dimension not previously articulated, which seems to facilitate the differentiating potential of corporate heritage stewardship by imbuing managers with a self-confidence to pursue non-conformist strategies and policies. The differentiating aspect of corporate heritage has been discussed in the literature in terms of positioning and its role as a strategic asset and resource (Urde et al., 2007; Balmer, 2011a; Hudson, 2011). It also lends supports the self-legitimating aspects of managerial corporate identity enactment in general (He and Balmer, 2007b). However, this study shows the importance of perceived independence and individuality shared by managers that is reinforced by the Sense of Responsibility and Sense of Belongingness converging into a managerial Positionality Awareness, which together with the awareness for the organisation's heritage and its heritage status in relation to stakeholders facilitates the manager's custodial role and the subsequent activities suggested in the extant literature for successful corporate heritage stewardship.

\section{Conclusion}

\section{Theoretical implications}

This study makes a theoretical contribution to the nascent area of corporate heritage brands and identities within the corporate marketing literature by introducing the corporate heritage identity stewardship theory that explicates three distinct but interrelated interpretative dimensions underpinned by six managerial dispositions in regard to corporate heritage identity stewardship expressed by managers, which are constitutive and instrumental for the strategic enactment of a corporate heritage identity.

As such, this empirical study confirms the saliency of the heritage stewardship notion in terms of a particular managerial mindset as introduced by Urde et al. (2007). Moreover, building on the above, it makes a theoretical contribution via the articulation of corporate heritage identity stewardship theory based on an empirical and exemplary single case. Further, our study is significant in that it not only 


\section{$28^{\text {th }}$ February, 2014}

confirms, specifies, and expands the extant two main dispositions suggested by Urde et al. (2007) focus on continuity (i.e. Sense of Continuance) and sense of responsibility - but also identifies additional managerial dispositions (i.e. Sense of Belongingness, Sense of Self, Sense of Heritage, Sense of Potency). It also expands the notion of stewardship beyond the original conceptualisation (in terms of heritage brands) in showing its applicability in regard to corporate heritage identities, which potentially broadens the concepts conceptual and empirical reach. Further, the theoretical framework contributes to the extant literature in that it categorises the different dimensions within a coherent framework of corporate heritage identity stewardship. The theoretical framework explicates the linkages between the different dispositions and articulates three main CHIS awareness dimensions expressed by managers (i.e. positionality awareness, heritage awareness, custodianship awareness). As such, this study advances the specificity and clarity of this nascent construct.

Five implications flow from this study: first, the managerial CHIS mindset is likely to be multifaceted rather than two-dimensional, which increases the construct's complexity and the number of empirical indicators required for further empirical (positivist) testing. Second, some of the identified dispositions may not directly impact on subsequent stewardship behaviour but may instead impact on other cognitive and affective intermediate dimensions constituting the managerial mindset For example, the study indicates that the three dispositions constituting the CHIS dimension positionality awareness may only impact on the other CHIS dimensions heritage awareness and custodianship awareness rather than stewardship behaviour directly, which has implications for the further operationalisation of the theory. Third, three interrelated CHIS dispositions (continuance, belongingness, and self) imply a confluence of temporal, spatial, and socio-cultural aspects of positionality awareness by managers rather than a focus solely on continuity/longevity (the temporal aspect alone) as suggested in the extant literature (Urde et al., 2007). Fourth, heritage awareness seems to be present as a fourth important dimension, which involves validating/valorising and protective aspects, with the latter providing a conceptual link to the notion of managerial identification discussed in the corporate marketing literature (He and Balmer, 2007b, 2013; He 2012). Five, the custodial dimension of the CHIS mindset not only entails an obligatory (responsibility) but also a legitimating dimension (potency). 


\section{$28^{\text {th }}$ February, 2014}

The importance accorded to the saliency of the spatial dimension for the enactment of the corporate heritage identity by managers in terms of perceived continuity as well as belongingness indicates that corporate marketing theory needs to be more attentive to questions of territoriality and spatial situatedness and provides an additional potential identity anchor employed by managers (He, 2012). Of course, such insights already characterise the corporate identity canon and it has been noted, for instance, that corporate identities are informed by various spatial and temporal dimensions (Balmer 2001a; 2008) and will, most probably, be relevant for certain types of corporate identities beyond the heritage focus of our research (e.g. regional corporate brands).

The reciprocal nature of the disposition of belongingness lends general support to the notion of reciprocity as a foundation of corporate heritage identity/brand saliency advanced by Balmer (2011a, 2011b) but shows that it is not restricted to the aspect of trust, but may include affinity as well. It also provides empirical evidence for the constitutive relevance of bilateral relationships between a corporate heritage identity/brand and other social entities as a source of legitimacy and relevance (Balmer, 2011a, 2011b).

Taking a broader vista, our study suggests that the general notion of management stewardship potentially carries conceptual and empirical significance/weight within a private sector context, at least for the management of particular types of organisations. As such, it opens a new avenue for crossdisciplinary fertilisation between the academic discourses within the domains of corporate heritage identities/brands and stewardship theory in management research (Davis et al., 1997; Hernandez, 2012) where the interests of the principle and agents are conflated based on higher order needs and intrinsic motivations focused on a reciprocal and collective mindset of obligation and duty towards the organisation (Hernandez, 2012) rather than individualistic and self-serving principles only (Davis et al., 1997).

Our study also indicates that the strategic enactment of corporate heritage identities/brands based on a particular mindset is not restricted to the CEO or the top management team (Vallaster and Lindgreen, 2011), although significantly influenced by their leadership (Vallaster and de Chernatony, 2006), but also shared by middle managers. 


\section{$28^{\text {th }}$ February, 2014}

Also, in terms of generic multi-dimensional corporate identity models discussed in the extant corporate marketing literature (e.g. Balmer and Soenen 1999; Balmer and Greyser, 2002, 2003; Balmer, 2008) the close interdependence between a managerial CHIS mindset and corporate heritage identity enactment that our study revealed indicates the convergence between the managerially conceived and the communicated corporate identity dimensions that manifest in cultural practices and artifacts constituting an important aspect of the 'actual' corporate identity in the present (see Balmer and Greyser, 2002).

Finally, from a family business perspective our study suggests that a focus on continuance and a long-term orientation may not only be a strategic success factor based on specific structural and corporate governance conditions (Le Breton-Miller and Miller, 2005) but also a potential marker of identity important for the constitution of heritage-imbued family business corporate identities/brands (Craig et al., 2008) representing a particular cognitive corporate identity anchor (He and Balmer 2007b; 2013; He, 2012) for managers of these types of organisations.

\section{Practical implications}

The corporate heritage identity stewardship theory framework has the potential to facilitate managers' understanding of their custodial role for a corporate heritage identity. In particular, maintaining the saliency of the corporate heritage identity vis-à-vis stakeholders in regard to trust, credibility, authenticity, and affinity requires a long-term orientation towards the business, an appreciation of the company' longevity, a dedication to the firm's survival as an independent institutional and legal entity, the maintenance of spatial and socio-cultural ties within and beyond the firm, as well as the willingness and ability to adapt and improve. Managers need to develop a clear sense of the organisation's 'place in the world', in terms of its past, present and future. In doing so, management should be empowered through being apprised of the independence imbuing the organisation which facilitates substantive differentiation and is manifest in a particular mode of managerial conduct.

Further, managers need to be able to identify, take ownership, and value the corporate heritage of their organisation. Thus, they need to accept their custodial role for the institutional heritage in order to keep it relevant over time. However, management also must be aware of the expanded responsibilities 


\section{$28^{\text {th }}$ February, 2014}

towards stakeholders, community, and society at large that the heritage status of their organisation entails. As such, the corporate identity takes on multiple role identities with which management needs to accommodate (see Balmer, 2008. 2011b). Failing to do so would eventually jeopardise the saliency of the corporate heritage and its relevance as a multi-faceted point of reference for stakeholder identification. Nonetheless, the heritage status of the organisation also provides management with the legitimacy and authority to act and speak not only for the organisation but also on behalf of others (e.g. industry issues, community issues etc.).

In light of the above, the study indicates the inherent complexity of corporate heritage identity stewardship. The management of heritage business institutions demands managerial attentiveness and an expanded skill sets that go beyond the mere economic, financial, and competitive concerns relevant for all business organisations in general. Hence, the successful management of corporate heritage identities is likely to be more demanding and difficult to achieve; requiring a well-rounded type of manager with - in addition to conventional business acumen and professional managerial and technical skills - a stewardship mindset that is attentive to past, present, and future as well as sensitive to temporal, spatial, and socio-cultural aspects of an organisation embedded within a societal environment.

The specified CHIS mindset supports managers by sensitising them to the different awareness dimensions and dispositions necessary for their custodial stewardship in regard to their organisation's corporate heritage identity.

\section{Limitations and future research}

The empirical scope of the study is limited to a single case within a particular industrial and geographical setting and as such statistical/substantive generalisation was not attempted or paradigmatically possible. However, the theoretical generalisation to a higher level of abstraction, which led to the articulation of the corporate heritage identity stewardship mindset framework derived from our empirical study, provides different avenues for future research. First, positivist studies may attempt to operationalise the different dimensions of the corporate heritage mindset in order to test relevant antecedents and consequences of the suggested corporate heritage identity stewardship theory. In terms of further research, the theoretical framework may facilitate future empirical work (e.g. 
quantitative modelling) as much as conceptual integration across disciplinary boundaries (e.g. stewardship theory in management). Further, the impact of the custodial role of managers and the interaction between different hierarchy levels as well as the diffusion of stewardship within the organisation provides interesting research opportunities. Finally, the suggested link between the managerial corporate heritage identity stewardship mindset and the dimensions of corporate heritage identity saliency vis-à-vis stakeholders warrant further empirical scrutiny.

\section{Concluding remarks}

This empirical study has advanced our theoretical understanding of the corporate heritage identity stewardship notion. Our research has revealed how managers within the UK's oldest brewery understand their organisation's corporate heritage and has shown that corporate heritage is marshalled, and strategically represented, by them. The research illustrates how a collective CHIS mindset on the part of managers can both inform, as well as guide, managers in terms of their stewardship of their firm's corporate heritage identity The resulting framework of the corporate heritage identity stewardship theory identifies the three CHIS awareness dimensions and six management CHIS dispositions, which informed their heritage custodianship of the brewery in a corporate marketing context. To reiterate, the purpose of the research is not to generalise to other cases. This being said, the findings have both a constitutive and instrumental relevance and, in accordance with the precepts of case study research are meaningful in its own terms and in corporate marketing contexts.

\section{References}

Aaker, D.A. (1996), Building strong brands, The Free Press, New York.

Abimbola, T. and Kocak, A. (2007), "Brand, organization identity and reputation: SMEs as expressive organizations. A resources-based perspective", Qualitative Market Research: An International Journal, Vol. 10 No. 4, pp. 416-430.

Abratt, R. and Kleyn, N. (2012), "Corporate identity, corporate branding and corporate reputations. Reconciliation and integration", European Journal of Marketing, Vol. 46 7/8, pp. 1048-1063.

Alexander, N. (2009), "Brand authentication. Creating and maintaining brand auras", European Journal of Marketing, Vol. 43 3/4, pp. 551-562.

Andriopoulos, C. and Gotsi, M. (2001), ''Living' the Corporate Identity: Case Studies from the Creative Industry", Corporate Reputation Review, Vol. 4 No. 2, p. 144.

Anheier, H.K. and Isar, Y.R. (Eds.) (2011), Heritage, memory \& identity, The cultures and globalization, Vol. 4, SAGE, London.

Ballantyne, R., Warren, A. and Nobbs, K. (2006), "The evolution of brand choice”, Journal of Brand

Management, Vol. 13 4/5, pp. 339-352.

Balmer, J.M.T. (1995), “Corporate Branding and Connoisseurship”, Journal of General 
Management, Vol. 21, No 1, Autumn, pp.24-47.

Balmer, J.M.T. (1996), "The nature of corporate identity. An explanatory study undertaken within BBC Scotland", PhD thesis, Department of Marketing, University of Strathclyde, Glasgow, 1996.

Balmer, J.M.T. (1998), "Corporate identity and the advent of corporate marketing", Journal of Marketing Management, Vol. 14 No. 8, pp. 963-996.

Balmer, J.M.T. (2001), "Corporate identity, corporate branding and corporate marketing - Seeing through the fog”, European Journal of Marketing, Vol. 35 3/4, pp. 248-291.

Balmer, J.M.T. (2008), "Identity based views of the corporation Insights from corporate identity, organisational identity, social identity, visual identity, corporate brand identity and corporate image", European Journal of Marketing, Vol. 42 9/10, pp. 879-906.

Balmer, J.M.T. (2009a), "Scrutinising the British Monarchy. The corporate brand that was shaken, stirred and survived", Management Decision, Vol. 47 No. 4, pp. 639-675.

Balmer, J.M.T. (2009b), "Corporate marketing. Apocalypse, advent and epiphany", Management Decision, Vol. 47 No. 4, pp. 544-572.

Balmer, J.M.T. (2011a), "Corporate heritage brands and the precepts of corporate heritage brand management . Insights from the British Monarchy on the eve of the royal wedding of Prince William (April 2011) and Queen Elizabeth II's Diamond Jubilee (1952-2012)", Journal of Brand

Management, Vol. 18 No. 8, pp. 517-544.

Balmer, J.M.T. (2011b), "Corporate heritage identities, corporate heritage brands and the multiple heritage identities of the British Monarchy", European Journal of Marketing, Vol. 45 9/10, pp. 1380-1398.

Balmer, J.M.T. (2011c), "Corporate marketing myopia and the inexorable rise of a corporate marketing logic: Perspectives from identity-based views of the firm”, European Journal of Marketing, Vol. 45 9/10, pp. 1329-1352.

Balmer, J.M.T. (2012a), "Strategic corporate brand alignment. Perspectives from identity based views of corporate brands", European Journal of Marketing, Vol. 46 7/8, pp. 1064-1092.

Balmer, J.M.T. (2012b), “Corporate Brand Management Imperatives: Custodianship, Credibility, and

Calibration", California Management Review, Vol. 54, No. 3, pp.6-33.

Balmer, J.MT. (2013), "Corporate heritage, corporate heritage marketing and total corporate heritage communications: What are they? What of them?" Corporate Communications: An International Journal, Vol. 18, No. 3, pp. 290-326.

Balmer, J.M.T. and Soenen, G. (1999), “The Acid Test of corporate identity management", Journal of Marketing Management, Vol. 15, No1-3, pp.69-72.

Balmer, J.M.T. and Greyser, S.A. (2002), "Managing the multiple identities of the corporation, California Management Review, Vol. 44, No 3, pp.72-86.

Balmer, J.M.T. and Greyser, S.A. (Eds.) (2003), Revealing the corporation: Perspectives on identity, image, reputation, corporate branding, and corporate-level marketing, An anthology, Routledge, London.

Balmer, J.M.T. and Greyser, S.A. (2006), "Corporate marketing. Integrating corporate identity, corporate branding, corporate communications, corporate image and corporate reputation", European Journal of Marketing, Vol. 40 7/8, pp. 730-741.

Balmer, J.M.T., Greyser, S.A. and Urde, M. (2004), Monarchies as corporate brands, Harvard Business School Working Paper, Boston.

Balmer, J.M.T., Greyser, S.A. and Urde, M. (2006), "The Crown as a corporate brand: Insights from monarchies", Journal of Brand Management, Vol. 14 1/2, pp. 137-161.

Balmer, J.M.T. and Stotvig, S. (1997), "Corporate identity and private banking: a review and case study", International Journal of Bank Marketing, Vol. 15 4/5, p. 169.

Balmer, J.M.T. and Stuart, H.J. (2004), British Airways and Balmer's $A C^{3} I D^{T M}$ test of corporate brand management, Bradford School of Management working paper, Bradford.

Balmer, J.M.T. and Wilson, A.M. (1998a), "Corporate identity. There is more to it than meets the eye", International Studies of Management \& Organization, Vol. 28 No. 3, pp. 12-31.

Banerjee, S. (2008), "Strategic brand-culture fit: A conceptual framework for brand management", Journal of Brand Management, Vol. 15 No. 5, pp. 312-321.

Bendixen, M. and Abratt, R. (2007), "Corporate identity, ethics and reputation in supplier-buyer relationships", Journal of Business Ethics, Vol. 76 No. 1, pp. 69-82.

Beverland, M.B. (2005), "Crafting brand authenticity: The case of luxury wines", Journal of Management Studies, Vol. 42 No. 5, pp. 1003-1029.

Beverland, M.B. (2006), "The 'real thing': Branding authenticity in the luxury wine trade", Journal of Business Research, Vol. 59 No. 2, pp. 251-258.

Blaikie, N. (2007), Approaches to social enquiry: Advancing knowledge, 2nd ed., Polity, Cambridge.

Blaikie, N. (2009), Designing social research: The logic of anticipation, 2nd ed., Polity, Cambridge. 
Blombäck, A. and Brunninge, O. (2009), "Corporate identity manifested through historical references”, Corporate Communications: An International Journal, Vol. 14 No. 4, pp. 404-419.

Blumer, H. (1969), Symbolic interactionism: Perspective and method, University of California Press, Berkeley.

Branchik, B.J. (Ed.) (2007), 2007 CHARM: Marketing History at the Center, $13^{\text {th }}$ Conference on Historical Analysis \& Research in Marketing Proceedings, CHARM Association, Durham, NC.

Bühler, H. and Dürig, U.-M. (Eds.) (2008), Tradition kommunizieren: Das Handbuch der Heritage Communication. Wie Unternehmen ihre Wurzeln und Werte professionell vermitteln, Frankfurter Allgemeine Buch, Frankfurt am Main.

Byrom, J. and Lehman, K. (2009), "Coopers Brewery: heritage and innovation within a family firm”, Marketing Intelligence \& Planning, Vol. 27 No. 4, pp. 516-523.

Charmaz, K. (2006), Constructing grounded theory, SAGE, London.

Chreim, S. (2005), "The continuity-change duality in narrative texts of organizational identity", Journal of Management Studies, Vol. 42 No. 3, pp. 567-593.

Corbin, J.M. and Strauss, A.L. (2008), Basics of qualitative research: Techniques and procedures for developing grounded theory, 3rd ed., SAGE, Los Angeles.

Craig, J.B., Dibrell, C. and Davis, P.S. (2008), "Leveraging family-based brand identity to enhance firm competitiveness and performance in family businesses", Journal of Small Business Management, Vol. 46 No. 3, pp. 351-371.

Davis, J.H., Schoorman, F.D. and Donaldson, L. (1997), "Toward a stewardship theory of management”, Academy of Management Review, Vol. 22 No. 1, pp. 20-47.

de Geus, A. (2002), The living company: Habits for survival in a turbulent business environment, Harvard Business School Press, Boston.

Denzin, N.K. and Lincoln, Y.S. (Eds.) (2005), The SAGE handbook of qualitative research, 3rd ed., Sage Publications, Thousand Oaks.

Easterby-Smith, M., Thorpe, R. and Jackson, P.R. (2008), Management research, 3rd ed., SAGE, London.

Eisenhardt, K.M. (1989), "Building theories from case study research", The Academy of Management Review, Vol. 14 No. 4, pp. 532-550.

Fionda, A.M. and Moore, C.M. (2009), "The anatomy of the luxury fashion brand", Journal of Brand Management, Vol. 16 5-6, pp. 347-363.

Flick, U. (1992), "Entzauberung der Intuition. Systematische Perspektiven-Triangulation als Strategie der Geltungsbegründung qualitativer Daten und Interpretationen”, in Hoffmeyer-Zlotnik, J.H.P. (Ed.), Analyse verbaler Daten: Über den Umgang mit qualitativen Daten, Westdeutscher Verlag, Opladen, pp. 11-55.

Flick, U. (2007), Managing quality in qualitative research, The sage qualitative research kit, SAGE, London.

Foster, W.M., Suddaby, R., Minkus, A. and Wiebe, E. (2011), "History as social memory assets. The example of Tim Hortons", Management \& Organizational History, Vol. 6 No. 1, pp. 101-120.

Gomm, R., Hammersley, M. and Foster, P. (Eds.) (2000), Case study method: Key issues, key texts, SAGE, London.

Goulding, C. (2000), "The commodification of the past, postmodern pastiche, and the search for authentic experiences at contemporary heritage attractions", European Journal of Marketing, Vol. 34 No. 7, pp. 835853.

Goulding, C. (2001), "Romancing the past. Heritage visiting and the nostalgic consumer", Psychology and Marketing, Vol. 18 No. 6, pp. 565-592.

Gourvish, T.R. and Wilson, R.G. (1994), The British brewing industry 1830-1980, Cambridge University Press, Cambridge.

Graham, B.J. and Howard, P. (2008), "Heritage and Identity", in Graham, B.J. and Howard, P. (Eds.), The Ashgate research companion to heritage and identity, Ashgate research companions, Ashgate, Aldershot, pp. $1-15$.

Graham, B.J. and Howard, P. (Eds.) (2008), The Ashgate research companion to heritage and identity, Ashgate research companions, Ashgate, Aldershot.

Gummesson, E. (2000), Qualitative methods in management research, 2nd ed., SAGE, London.

Hakala, U., Lätti, S. and Sandberg, B. (2011), "Operationalising brand heritage and cultural heritage", Journal of Product \& Brand Management, Vol. 20 No. 6, pp. 447-456.

Hamel, J. (1992), "The case study method in sociology - introduction. New theoretical and methodological issues", Current Sociology, Vol. 40 No. 1, pp. 1-7.

Hammersley, M. and Gomm, R. (2000), "Introduction", in Gomm, R., Hammersley, M. and Foster, P. (Eds.), Case study method: Key issues, key texts, SAGE, London, pp. 1-16.

Harper, D. (1992), "Small N's and community case studies", in Ragin, C.C. and Becker, H.S. (Eds.), What is a case? Exploring the foundations of social inquiry, Cambridge University Press, Cambridge, pp. 139-158.

He, H.-W. (2004), "Explaining the relationship between identity and strategy: A grounded theory approach", $\mathrm{PhD}$ thesis, School of Management, University of Bradford, Bradford, 2004. 
He, H.-W. (2012), “Corporate identity anchors. A managerial cognition perspective”, European Journal of Marketing, Vol. 46 No. 5, pp. 609-625.

He, H.W., and Balmer, J.M.T. (2007a) Identity Studies: Multiple Perspectives and Implications for Corporate-Level Marketing, European Journal of Marketing, Vol. 41, No 7\&8, pp. 765787.

He, H.-W. and Balmer, J.M.T. (2007b), "Perceived corporate identity/strategy dissonance: triggers and managerial responses", Journal of General Management, Vol. 33 No. 1, pp. p71 - 91.

He, H.-W. and Balmer, J.M.T. (2013), "The corporate identity/strategy dynamic. A grounded theory study of building societies from a corporate marketing perspective", European Journal of Marketing, Vol. 47 3/4.

Hernandez, M. (2012), "Toward an understanding of the psychology of stewardship", Academy of Management Review, Vol. 37 No. 2, pp. 172-193.

Hildebrand, D., Sen, S. and Bhattacharya, C.B. (2011), "Corporate social responsibility: a corporate marketing perspective”, European Journal of Marketing, Vol. 45 No. 9/10, pp. 1353-1364.

Hoffmeyer-Zlotnik, J.H.P. (Ed.) (1992), Analyse verbaler Daten: Über den Umgang mit qualitativen Daten, Westdeutscher Verlag, Opladen.

Holt, D.B. (2004), How brands become icons: The principles of cultural branding, Harvard Business School Press, Boston.

Hudson, B.T. (2011), "Brand heritage and the renaissance of Cunard", European Journal of Marketing, Vol. 45 9/10, pp. 1538-1556.

Isar, Y.R., Viejo-Rose, D. and Anheier, H.K. (2011), "Introduction", in Anheier, H.K. and Isar, Y.R. (Eds.), Heritage, memory \& identity, The cultures and globalization, SAGE, London, pp. 1-20.

Knowles, T. and Egan, D. (2002), "The changing structure of UK brewing and pub retailing", International Journal of Contemporary Hospitality Management, Vol. 14 No. 2, pp. 65-71.

Lee, N. and Lings, I. (2008), Doing business research: A guide to theory and practice, SAGE, London.

Leitch, S. and Davenport, S. (2011), "Corporate identity as an enabler and constraint on the pursuit of corporate objectives”, European Journal of Marketing, Vol. 45 No. 9/10, pp. 1501-1520.

Liebrenz-Himes, M., Shamma, H. and Dyer, R.F. (2007), "Heritage brands - Treasured inheritance or "over the hill"', in Branchik, B.J. (Ed.), 2007 CHARM: Marketing History at the Center, $13^{\text {th }}$ Conference on Historical Analysis \& Research in Marketing Proceedings, John W. Hartman Center for Sales, Advertising \& Marketing History, Duke University, 17-20 May 2007, CHARM Association, Durham, NC, pp. 140-145.

Lowenthal, D. (1998), The heritage crusade and the spoils of history, Cambridge University Press, Cambridge.

Mathias, P. (1959), The brewing industry in England, 1700-1830, Cambridge University Press, Cambridge.

Maxwell, R. and Knox, S. (2009), "Motivating employees to "live the brand": A comparative case study of employer brand attractiveness within the firm", Journal of Marketing Management, Vol. 25 9/10, pp. 893907.

McDonald, H. (2011), "Understanding the antecedents to public interest and engagement with heritage", European Journal of Marketing, Vol. 45 No. 5, pp. 780-804.

Melewar and Akel, S. (2005), "The role of corporate identity in the higher education sector: A case study", Corporate Communications: An International Journal, Vol. 10 No. 1, pp. 41-57.

Micelotta, E.R. and Raynard, M. (2011), "Concealing or revealing the family? Corporate brand identity strategies in family firms", Family Business Review, Vol. 24 No. 3, pp. 197-216.

Miller, D. and Le Breton-Miller, I. (2005), Managing for the long run: Lessons in competitive advantage from great family businesses, Harvard Business School Press, Boston.

Moore, C.M. and Birtwistle, G. (2004), “The Burberry business model. Creating an international luxury fashion brand", International Journal of Retail \& Distribution Management, Vol. 32 No. 8, pp. 412-422.

Motion, J., Leitch, S. and Brodie, R.J. (2003), "Equity in corporate co-branding: The case of Adidas and the All Blacks", European Journal of Marketing, Vol. 37 7/8, pp. 1080-1094.

Muir, R. (2012), Pubs and places: The social value of community pubs. $2^{\text {nd }}$ edn, IPPR, London, Available at: http://www.ippr.org/publications/55/8519/pubs-and-places-the-social-value-of-community-pubs.

Oxford Economics (2012), BBPA: Local impact of the beer and pub sector 2010/11. A report for the British Beer and Pub Association, Oxford Economics, Oxford, Available at: http://www.beerandpub.com/industrybriefings/oxford-economics-local-impact-of-the-beer-and-pub-sector-2010-11.

Peñaloza, L. (2000), "The commodification of the American west: Marketers' production of cultural meanings at the trade show", Journal of Marketing, Vol. 64 No. 4, pp. 82-109.

Ponsonby-McCabe, S. and Boyle, E. (2006), "Understanding brands as experiential spaces. Axiological implications for marketing strategists", Journal of Strategic Marketing, Vol. 14 No. 2, pp. 175-189.

Powell, S.M. (2005), "Creativity and the corporate brand within small to medium sized creative organisations", PhD thesis, Department of Marketing, University of Strathclyde, Glasgow, 2005. 
Powell, S.M. (2011), “The nexus between ethical corporate marketing, ethical corporate identity and corporate social responsibility: An internal organisational perspective”, European Journal of Marketing, Vol. 45 9/10, pp. $1365-1379$.

Pratten, J. (2007a), "The development of the modern UK public house: Part 1, The traditional British public house of the twentieth century", International Journal of Contemporary Hospitality Management, Vo. 19 No. 4, pp. 335-342.

Pratten, J. (2007b), "The development of the UK public house: Part 2, Signs of change to the UK public house 1959-1989”, International Journal of Contemporary Hospitality Management, Vol. 19 No. 6, pp. 513-519.

Pratten, J. (2007c), "The development of the modern UK public house: Part 3, The emergence of the modern public house 1989-2005”, International Journal of Contemporary Hospitality Management, Vol. 19 No. 7 , pp. 612-618.

Ragin, C.C. and Becker, H.S. (Eds.) (1992), What is a case? Exploring the foundations of social inquiry, Cambridge University Press, Cambridge.

Samuel, R. (1996), Theatres of memory: Past and present in contemporary culture, Volume 1, Verso, London.

Sayer, A. (1992), Method in social science: A realistic approach, 2 nd ed., Routledge, London.

Schütz, A. (1962), Collected papers I: The problem of social reality, Edited by Maurice Natanson, Phaenomenologica, Vol. 11, Martinus Nijhoff, The Hague.

Sheen, D. ed. (2011), British Beer \& Pub Association: Statistical handbook 2011. A compilation of drinks industry statistics, Brewing Publications, London.

Segal, L. and Lehrer, M. (2012), “The institutionalization of stewardship. Theory, propositions, and insights from change in the Edmonton Public Schools", Organization Studies, Vol. 33 No. 2, pp. 169-201.

Siggelkow, N. (2007), "Persuasion with case studies", The Academy of Management Journal, Vol. 50 No. 1, pp. 20-24.

Simões, C.M.N. and Mason, K.J. (2012), "Informing a new business-to-business relationship:. Corporate identity and the emergence of a relationship identity", European Journal of Marketing, Vol. 46 No. 5, pp. 684-711.

Stadler, C. (2011), Enduring success: What we can learn from the history of outstanding corporations, Stanford Business Books, Stanford.

Stake, R.E. (1995), The art of case study research, Sage Publications, Thousand Oaks.

Stake, R.E. (2005), "Qualitative case studies", in Denzin, N.K. and Lincoln, Y.S. (Eds.), The SAGE handbook of qualitative research, 3rd ed., Sage Publications, Thousand Oaks, pp. 443-466.

Urde, M. (2009), "Uncovering the corporate brand's core values”, Management Decision, Vol. 47 No. 4, pp. 616-638.

Urde, M., Greyser, S.A. and Balmer, J.M.T. (2007), "Corporate brands with a heritage”, Journal of Brand Management, Vol. 15 No. 1, pp. 4-19.

Vallaster, C. and de Chernatony, L. (2005), "Internationalisation of Services Brands: The Role of Leadership During the Internal Brand Building Process", Journal of Marketing Management, Vol. 21 1-2, pp. 181-203.

Vallaster, C. and de Chernatony, L. (2006), "Internal brand building and structuration. The role of leadership", European Journal of Marketing, Vol. 40 7/8, pp. 761-784.

Vallaster, C. and Lindgreen, A. (2011), "Corporate brand strategy formation. Brand actors and the situational context for a business-to-business brand”, Industrial Marketing Management, Vol. 40 No. 7, pp. 11331143.

Verschuren, P. (2003), "Case study as a research strategy. Some ambiguities and opportunities", International Journal of Social Research Methodology, Vol. 6 No. 2, pp. 121-139.

Walton, J. (1992), "Making the theoretical case", in Ragin, C.C. and Becker, H.S. (Eds.), What is a case? Exploring the foundations of social inquiry, Cambridge University Press, Cambridge, pp. 121-137.

Wiedmann, K.-P., Hennigs, N., Schmidt, S. and Wuestefeld, T. (2011a), "Drivers and Outcomes of Brand Heritage: Consumers' Perception of Heritage Brands in the Automotive Industry", The Journal of Marketing Theory and Practice, Vol. 19 No. 2, pp. 205-220.

Wiedmann, K.-P., Hennigs, N., Schmidt, S. and Wuestefeld, T. (2011b), "The importance of brand heritage as a key performance driver in marketing management”, Journal of Brand Management, Vol. 19 No. 3, pp. 182194.

Yin, R.K. (2009), Case study research: Design and methods, Applied social research methods, Vol. 5, 4th ed., SAGE, London. 


\section{Appendix}

\begin{tabular}{|c|c|}
\hline \multicolumn{2}{|c|}{ Exhibit 1: Sense of continuance } \\
\hline $\begin{array}{l}\text { Focus on } \\
\text { continuity }\end{array}$ & $\begin{array}{l}\text { Explanation: } \\
\text { Relates to an appreciation and dedication by managers in terms of the company's continuity over time } \\
\text { (temporal), the firm's continued institutional existence (institutional), the continuity of place and } \\
\text { location (spatial), and the importance accorded to the continuity in stakeholder relationships (social) } \\
\text { Illustrative interview quotes: } \\
\text { "And I think fundamentally, whilst it certainly makes good business sense, there have been arguments } \\
\text { at times to say do we carry on brewing? Is that economic? Do we split the company up? But in all of } \\
\text { those debates really the overriding thing has been to maintain the company." (director) } \\
\text { "... I think when people come to the brewery, look at its site, its location, just get a feel of the spirit of } \\
\text { the place, you actually realise this is a bit different." (director) } \\
\text { "It's what I always say is that there's a huge number of people involved in Shepherd Neame whose } \\
\text { own families have been involved here for many, many, many years [...] They're the people that set the } \\
\text { culture of the business [...] about } 150 \text { staff have done more than ten years and damn near 100 staff } \\
\text { have done } 20 \text { years or more" (director) } \\
\text { "Oh, we're three hundred years old," and it rolls off the tongue quite easily, but it's not until you } \\
\text { think what Britain was like three hundred years ago that you appreciate quite what this company's } \\
\text { been through." (manager) } \\
\text { Illustrative additional evidence: } \\
\text { It is strategically manifested in the company's shareholding structure and the dedication of the current } \\
\text { owners to maintain the company. It is a recurrent theme in the annual reports and other corporate } \\
\text { communication materials related to investor relations justifying the integrated business model pursued. } \\
\text { Company policies reward long-term loyalty of staff and business partners. }\end{array}$ \\
\hline $\begin{array}{l}\text { Focus on the } \\
\text { long-term }\end{array}$ & $\begin{array}{l}\text { Explanation: } \\
\text { Refers to a long-term managerial orientation and view of the business fundamentally guiding } \\
\text { management decisions and strategies } \\
\text { Illustrative interview quotes: } \\
\text { "Everything that I face here with the decisions we make today, we kind of want to stand by them in } 5 \\
\text { years time, in } 10 \text { years time." (director) } \\
\text { "It definitely leads to long-term thinking and focuses the whole time on business optimisation rather } \\
\text { than, where's the next deal around?" (director) } \\
\text { "They're [the board] happy to look decades ahead in the decisions that they make, and that's } \\
\text { something else we use [for corporate marketing] as well and that takes you all the way back three } \\
\text { hundred years." (manager) } \\
\text { "It's not just about making money. Of course that's an important thing, but there does seem to be that } \\
\text { longer term view on things." (manager) } \\
\text { Illustrative additional evidence: } \\
\text { The long-term view is explicitly included in the company value statement and reflected in the } \\
\text { investment decisions the company makes, which are focused on incremental improvements and } \\
\text { organic continuous growth. Throughout its history the business has constantly invested in new } \\
\text { technology in order to improve the productivity, efficiency, and sustainability of its operations and the } \\
\text { quality of its services and pub estate and has successfully managed to survive as the last independent } \\
\text { brewery in Kent. }\end{array}$ \\
\hline
\end{tabular}




\begin{tabular}{|l|l|}
\hline $\begin{array}{l}\text { Focus on } \\
\text { adaptation }\end{array}$ & $\begin{array}{l}\text { Explanation: } \\
\text { Refers to the appreciation for the necessity to adapt and constantly improve, which was understood as } \\
\text { an important antecedent for the very endurance and longevity of the organisation }\end{array}$ \\
$\begin{array}{l}\text { Illustrative interview quotes: } \\
\text { "I think we're very early adopters of new technology. I think that goes way back to... in fact it goes } \\
\text { back through the Shepherd family. If you look at some of the things that have happened in the past } \\
\text { here, we were one of the first breweries to have a steam engine back in 1789, we were one of the first } \\
\text { to get out of horses and steam traction, one of the first to have early things like PDX technology, our } \\
\text { new bottling line, our SAP IT information system. We're very willing to be experimental with new } \\
\text { technology as producers. And I suspect that is quite deep seated here." (director) }\end{array}$ \\
$\begin{array}{l}\text { "...ultimately Shepherd Neame's success, I think, is being able to grasp the nettle, the thorn, at the } \\
\text { time and say, 'Actually we need a different skill set or we need a different approach to our asset base." } \\
\text { And we must have done that in one form or another over the } 300 \text { years, from bringing in the very first } \\
\text { beer trains to London, to this fancy bottling line, to buying new pubs, to all sorts of things." (director) } \\
\text { Illustrative additional evidence: } \\
\text { Throughout its history the company went through periods of stability and periods of rapid change but } \\
\text { each time the management at the time recognised the need for change and acquired the necessary } \\
\text { capabilities and resources to answer challenges and grasp opportunities. }\end{array}$
\end{tabular}

\begin{tabular}{|c|c|}
\hline \multicolumn{2}{|c|}{ Exhibit 2: Sense of belongingness } \\
\hline $\begin{array}{l}\text { Focus on } \\
\text { closeness/ } \\
\text { provenance }\end{array}$ & $\begin{array}{l}\text { Explanation: } \\
\text { Refers to the importance accorded to spatial (place and location) and socio-cultural (collective, } \\
\text { institutional) proximity and origin (inside and outside the company). } \\
\text { Illustrative interview quotes: } \\
\text { "We get involved in all manner of different social and sports and school events and what have you } \\
\text { and it does make a difference because we very much feel that we are from here and part of here ... } \\
\text { We're very much involved in everything that goes on. And I think that gives us great strength in some } \\
\text { regards and loyalty and I think people know who we are, we're good employers, we're seen as a savvy } \\
\text { and successful business. Of course, this all helps. I think it is very important. It defines us in some } \\
\text { way." (director) } \\
\text { "I think there's a feeling of ownership in Kent. I think that's probably the other thing. I think that } \\
\text { people feel that Shepherd Neame pubs are their pubs. Whereas all the others, with the exception of } \\
\text { free houses, are interlopers, if you like." (director) } \\
\text { "I think geographically we're quite tucked away in a corner. It's kind of like a frontier land, very } \\
\text { close to the continent and in that regard we've been able to create an estate in a corner, our little } \\
\text { corner of England where we can defend both our estate and our trade..." (director) } \\
\text { "We [the board] enjoy talking to people and enjoy interacting. I think we want to be part of the team, } \\
\text { want to be stuck in. [...] the philosophies towards people, where people, I hope, would say that it's a } \\
\text { transparent culture, an open culture, it's certainly not a closed door culture." (director) } \\
\text { "The brewery does a hell of a lot for Kent and we've started doing more in Essex, Surrey, and Sussex } \\
\text { where our trading areas have developed. They've [the board] made it a kind of thing to get into the } \\
\text { society of a county..." (manager) } \\
\text { (manager) }\end{array}$ \\
\hline
\end{tabular}




\begin{tabular}{|l|l|}
\hline $\begin{array}{l}\text { It's [the company] seen very much as part of the community and because it's right in the heart of the } \\
\text { town I think that's reinforced." (manager) } \\
\text { "For example, you've probably heard this before, but [the CEO] knows everybody and will stop and } \\
\text { talk to everybody and that is important and I guess in many ways that has affected the way I portray } \\
\text { myself [as a manager]..." (manager) }\end{array}$ \\
$\begin{array}{l}\text { Illustrative additional evidence: } \\
\text { It is supported by active sponsorship, corporate philanthropy, and the involvement in local and } \\
\text { regional festivals. It also empirically manifests in the way the company premises (e.g. visitor centre) } \\
\text { are used for concerts and other activities involving the community (e.g. weddings). It is reinforced by } \\
\text { the use of PGI certification under the EU scheme for some of the company's beers as well as local } \\
\text { food initiatives and the focus on regional suppliers. The company actively uses the association with } \\
\text { the town and county for its corporate marketing and constantly refers to its Kentish origins and its } \\
\text { close links with the communities of Kent as well as features on a timeline at the Museum of London } \\
\text { and is associated with the Royal Albert Hall reinforcing the company's link with London and the UK. }\end{array}$ \\
\hline
\end{tabular}

\begin{tabular}{|c|c|}
\hline \multicolumn{2}{|c|}{ Exhibit 3: Sense of self } \\
\hline $\begin{array}{l}\text { Focus on } \\
\text { independence/ } \\
\text { individuality }\end{array}$ & $\begin{array}{l}\text { Explanation: } \\
\text { Refers to the importance accorded to autonomy, plurality, and difference in feeling, thinking, and } \\
\text { acting as and on behalf of the company. } \\
\text { Illustrative interview quotes: } \\
\text { "We're quite resistant to sort of follow industry initiatives, and so I think that's part of the } \\
\text { characteristic of the business. [...] we're independent, proudly independent and expect to remain so." } \\
\text { (director) } \\
\text { "I think we're quite an independent-thinking company. We don't just do what everyone else does. In } \\
\text { fact, more often it is the case - and this is people coming to me and telling me this from other } \\
\text { companies - that they look to Shepherd Neame to see what we're up to. [...]Because I think that we } \\
\text { are independent thinkers and I think that is something that is different [about this company]." } \\
\text { (director) } \\
\text { "You know, you get also that sense of individualism [with the pubs] as well. The Sheps [Shepherd } \\
\text { Neame] pubs have character, even the managed houses, and the consumer nowadays is, not } \\
\text { exclusively but often, aware of the difference between... all those sort of cut-and-paste McDonalds } \\
\text { pubs." (director) } \\
\text { "I think the great thing about Shepherd Neame is that there isn't a Shepherd Neame way of doing it, } \\
\text { and I think that's one of the great things about the company [...] I don't think there is a generic way } \\
\text { of doing things around here, at all." (manager) } \\
\text { Illustrative additional evidence: } \\
\text { The company has tended to introduce its own initiatives in regard to certain policies and strategies } \\
\text { independence and autonomy. }\end{array}$ \\
\hline
\end{tabular}




\begin{tabular}{|c|c|}
\hline \multicolumn{2}{|c|}{ Exhibit 4: Sense of heritage } \\
\hline $\begin{array}{l}\text { Heritage } \\
\text { validation }\end{array}$ & $\begin{array}{l}\text { Explanation: } \\
\text { Refers to the recognition and acknowledgement of the institutional heritage and the heritage status. } \\
\text { Illustrative interview quotes: } \\
\text { "I think there's terrific pride in the heritage of the business." (director) } \\
\text { "Britain's oldest brewer. Have been here since at least } 1698 \text { - probably longer than that, possibly } \\
\text { back as far as the early 1500s. So we have a very strong sense of history and heritage." (manager) } \\
\text { Illustrative additional evidence: } \\
\text { On the company website it states, for instance, that "[t]he company has a genuine interest in history" } \\
\text { something that was already apparent in historical marketing documents going back to the 1950s. }\end{array}$ \\
\hline $\begin{array}{l}\text { Heritage } \\
\text { appreciation }\end{array}$ & $\begin{array}{l}\text { Explanation: } \\
\text { Refers to the valuation and estimation of the institutional heritage and the heritage status. } \\
\text { Illustrative interview quote: } \\
\text { "We are clearly very aware of our heritage, the fact that the company was one of the first to be } \\
\text { registered as a company, the fact that we've been brewing on this site actually not since } 1698 \text {, it's } \\
1570 \text { - research has taken it further back. So, at that level, one is very aware of the family involvement, } \\
\text { the history, the longevity of the business and the fact that we've owned properties for nearly } 300 \text { years, } \\
\text { which is very unusual." (director) } \\
\text { Illustrative additional evidence: } \\
\text { The phrase "We are extremely proud to be Britain's Oldest Brewer" is an explicit part of the } \\
\text { company's value statement, which has prefaced every annual report since } 2005 \text {. }\end{array}$ \\
\hline $\begin{array}{l}\text { Heritage } \\
\text { adoption }\end{array}$ & $\begin{array}{l}\text { Explanation: } \\
\text { Refers to the acceptance and in possession taking of the institutional heritage and the heritage status. } \\
\text { Illustrative interview quotes: } \\
\text { "So I think a lot of that history and heritage gives an atmosphere that is ingrained in everything that } \\
\text { happens, rather than it necessarily being something that - it's more subconscious than overt, I would } \\
\text { say, with a lot of the things that go on here." (manager) } \\
\text { "I think the most important key points are, as we've just said, that the company's heritage is one of } \\
\text { our key advantages going forward." (manager) } \\
\text { Illustrative additional evidence: } \\
\text { It is reflected in the archivist's task is not only to systematise and organise the vast collection of } \\
\text { historical documents and archival materials accumulated by the company over the years, but also to } \\
\text { provide historical information and data that can be used for corporate marketing purposes. }\end{array}$ \\
\hline
\end{tabular}

\begin{tabular}{|l|l|}
\hline \multicolumn{2}{|l|}{ Exhibit 5: Sense of responsibility } \\
\hline $\begin{array}{l}\text { Institutional } \\
\text { custodianship }\end{array}$ & $\begin{array}{l}\text { Explanation: } \\
\text { Refers to the perceived custodial obligation towards the institutional heritage and the organisation's } \\
\text { heritage status }\end{array}$ \\
& $\begin{array}{l}\text { Illustrative interview quotes: } \\
\text { "There have been one or two potential decisions that we didn't take which would have shaken the } \\
\text { thing to the core. Now, whether in the future, similar decisions come up and we do take them I don't } \\
\text { know. But I think that generally we've trod the path of trying to maintain the company with its core } \\
\text { values." (director) }\end{array}$ \\
\hline
\end{tabular}




\begin{tabular}{|c|c|}
\hline & $\begin{array}{l}\text { "The most important thing, I think, about the company and the people who run it ... is that it's almost } \\
\text { like just... I get the sense that it's like being the custodian of something and it almost feels like they } \\
\text { [the board] don't want to be the one to drop the ball because it's got to pass on to someone else after } \\
\text { they're not involved any more, or they've died or something, in years to come. (manager) } \\
\text { "I think the Board cares, I really do think they do, and I think the management feels a sense of } \\
\text { responsibility for what's gone before and where the company will be in the future too. It's not just } \\
\text { about today you know [...] There seems to be an overarching sense of responsibility, which filters } \\
\text { down from the directors really." (manager) } \\
\text { I think the most important key points are, as I've just said, that the company's heritage is one of our } \\
\text { key advantages going forward. In the tough business world, it's something we should use and exploit } \\
\text { but carefully and being mindful that it's a valuable but quite fragile thing in some ways. And also that } \\
\text { actually, probably without knowing it, we are doing a lot of that already. [...] So that's the part that } \\
\text { has always fascinated me about the company and that you're only here really, I'm sitting in this office, } \\
\text { but I'm only a tiny speck on the history of the company." (manager) } \\
\text { Illustrative additional evidence: } \\
\text { It is facilitated by the governance and ownership structure of the business and reflected in the } \\
\text { ownership of many historic buildings. }\end{array}$ \\
\hline $\begin{array}{l}\text { Non- } \\
\text { institutional } \\
\text { custodianship }\end{array}$ & $\begin{array}{l}\text { Explanation: } \\
\text { Refers to the perceived custodial duty beyond the organisation itself predicated on the heritage status } \\
\text { of the organisation } \\
\text { Illustrative interview quotes: } \\
\text { "We want to be a premium long-term benevolent company that has responsibility in terms of the } \\
\text { environmental impact and responsibility in terms of the employment of the people and in terms of the } \\
\text { support to the community. [...] we have a desire to produce great quality products, a desire to be } \\
\text { proud of the community in which we work in and support, being able to give something back to the } \\
\text { community as well as deliver a sales performance, and ultimately a return to the shareholders." } \\
\text { (director) } \\
\text { "I think it is important because we take our responsibilities - and without trying to sound too trite- } \\
\text { we take our responsibilities within the community quite seriously, or very seriously." (director) } \\
\text { "I think part of it is the fact that it is Britain's oldest brewer so there is that importance there. A lot } \\
\text { of the pubs are historic in their own right. So we own more listed buildings in Kent than the National } \\
\text { Trust or English Heritage. And with that come some responsibilities..." (manager) } \\
\text { "It must be intimidating [for the directors] in terms of well, we'd better make sure we do the right } \\
\text { thing here, both in terms of business decisions but also the community because it's [the company] } \\
\text { become such a part of the community, obviously a big employer in the town and the farms all around } \\
\text { supplying it, and to have become part of the fabric of Faversham." (manager) } \\
\text { Illustrative additional evidence: } \\
\text { Evidence for policies and strategies that support these claims can be traced back to the late } 19^{\text {th }} \text { century } \\
\text { and early } 20^{\text {th }} \text { century (e.g. pension and hardship funds, community involvement). It is manifested in } \\
\text { various policies and activities of the company testified by industry awards that substantiate the } \\
\text { corporate responsibility and sustainability claims as well as the custodial role claimed by the company } \\
\text { for cultural heritage at different levels (e.g. brewing heritage, pub heritage, hop growing heritage etc.) }\end{array}$ \\
\hline
\end{tabular}




\begin{tabular}{|c|c|}
\hline \multicolumn{2}{|c|}{ Exhibit 6: Sense of potency } \\
\hline $\begin{array}{l}\text { Corporate } \\
\text { purpose and } \\
\text { authority }\end{array}$ & $\begin{array}{l}\text { Explanation: } \\
\text { Refers to the perceived corporate vocation and legitimacy to engage in issues not only in regard to the } \\
\text { company itself (e.g. interests, strategies, and policies) but also in terms of issues beyond immediate } \\
\text { institutional concern } \\
\text { Illustrative interview quotes: } \\
\text { "There's a self confidence about the business too. I mean we do want to be a leader not a follower. It } \\
\text { doesn't mean we want to cock a snoop at everyone, but we do want to pursue our own path." (director) } \\
\text { "I think it's typical Sheps [Shepherd Neame]... I think you'd have to know the company reasonably } \\
\text { well, or Kent reasonably well, but I think everything from the challenge to the duty in the '90s, to [our] } \\
\text { more recent challenge to duty on alcohol... You know, we like to be involved in the democratic process. } \\
\text { You know, we've got a democracy, let's use it." (director) } \\
\text { "I think we're involved heavily in industry discussions and matters so [the current CEO] now, but [his } \\
\text { predecessor] before him, was a resounding voice in the industry..." (director) } \\
\text { "So I think it's a case of sort of punching above its weight a little, I suppose, it's all about looking } \\
\text { after beer, looking after pubs, and it's, you know, for a relatively small, regional brewer. So compared } \\
\text { to the big brewers I think the company gets a lot more coverage [in the media]." (director) } \\
\text { "We've produced beer for the longest in the country and that's a heritage that works very much in } \\
\text { our favour... that heritage is very important. I would say definitely, for me, dealing day to day with } \\
\text { responsible authorities and what I mean by that, that's the council, the police and everything. It makes } \\
\text { my day to day life much easier." (manager). } \\
\text { Illustrative additional evidence: } \\
\text { to puanifests, for instance, in company activities such as a campaign against rising beer duties in the } \\
\text { involved in industry bodies and public debates (e.g. CEO as chairman of the British Beer and Pub } \\
\text { Association). }\end{array}$ \\
\hline
\end{tabular}




\section{TABLES}

\section{Table 1: Corporate heritage brand/identity characteristics}

\section{Temporality}

Corporate heritage brands and identities inhabit multiple temporal time frames in that they are of the past, present, and future (Balmer et al., 2006; Urde et al., 2007): these time identities afford corporate heritage an especial quality and may account for their saliency vis-à-vis different stakeholders (Balmer, 2011b). Hence, corporate heritage brands and corporate heritage identities are imbued with a quality of "timelessness" (Urde et al., 2007) and as such often act as a stable point of reference (Balmer et al., 2006) for individual and collective identities within and beyond the individual institution (Balmer, 2011a). Both concepts - corporate heritage brands and corporate heritage identities - are predicated on an apparent temporal transcendence of certain characteristic corporate identity traits - the heritage footprint of a corporate identity (Balmer, 2011a) - that constitute an institutional heritage (i.e. corporate heritage), being different from history or the past per se (Urde et al., 2007; Balmer, 2011a, 2011b). Hudson (2011), for instance, showed how these different timeframes are mutually constructed by the company and the customers of the Cunard shipping brand of ocean liners and cruise ships.

\section{Continuity}

The importance of continuity in terms of core brand values and in terms of symbols as well as continuity in regard to performance over time (i.e. track record) has been identified as a key trait of corporate heritage brands (Urde et al., 2007). For example, Wiedmann et al. (2011a, 2011b) have shown that the perceived value customers' attach to heritage in the context of automobile corporate brands in Germany is related to higher trustworthiness and affinity due to credibility and orientation derived from long-term continuity and values expressed by the heritage status of a corporate brand.

\section{Relative Invariance}

Corporate heritage brands and identities are characterised by a "relative invariance." This theoretical notion can be explained in terms of that organisations over time "appear to remain the same and yet change" (Balmer, 2011b, p. 1387). As such, the institutional heritage is adapted and reinterpreted for present purposes and in the light of expectations for the future (Urde et al., 2007, Balmer, 2011b). For instance, Byrom and Lehman (2009) evidenced how the Australian Coopers brewery managed to facilitate its institutional heritage as a family business while maintaining the company's contemporary appeal and relevance.

\section{Multiple Role Identities}

Corporate heritage identities/brands may also be constituted in relation to the cultural heritage of other social entities such as communities or places as well as form meaningful bilateral relationships with other corporate heritage brands or identities (Balmer, 2011a, 2011b) providing a much broader base for an organisation's legitimacy and stakeholder relevance (Balmer, 2011b). For example, a recent study by Foster, Suddaby, Minkus and Wiebe (2011) - albeit using different theoretical concepts - shows how the Canadian fast-food brand Tim Horton explicitly appropriated Canadian national heritage. Brand identity and brand positioning and insofar has become a stable reference point for Canadian collective identity. 


\section{Table 2: Shepherd Neame company information}

Shepherd Neame Ltd. is a regional brewer and pub operator based in the small English market town of Faversham in the county of Kent. The company is a $5^{\text {th }}$ generation family controlled business founded in 1698 (although recent historical evidence indicates that the origins of the brewery can be traced well into the $16^{\text {th }}$ century), which qualifies it as Britain's oldest brewery. The Company owns about 354 pubs and a growing number of hotels in Kent and the South East of England (including London). It brews nationally distributed cask ales ("Real Ale") and premium bottled ales (PBA) such as "Spitfire" or "Bishops Finger", which are PGI (Protected Geographical Indication) certified under EU legislation, as well as several international premium lagers such as Asahi Super Dry (Japan) or Kingfisher (India) and speciality craft beers such as Samuel Adams (US) under license. The shareholding of the company is divided into shares held exclusively by family members and shares traded on the London PLUS Market (recently renamed into ICAP ISDX Exchange). In 2012 Shepherd Neame brewed 252,000 barrels (UK) of beer (approx. 412,400 hectoliters) with a record annual turnover of over $£ 133$ million. Before the current recession the company had enjoyed continuous year on year profit and turnover growth for more than three decades and has continued to outgrow the market since 2008 . The company has managed to grow against the backdrop of a highly competitive and regulated business environment, characterised by high levels of market concentration (market dominated by a few multi-national breweries, pub companies and multiple retailers), brewery and pub closures, unfavorable government legislation and tax policy, decline in beer consumption, and changing customer preferences and lifestyle patterns. The majority of the sales are made in the UK (with some notable export successes to Sweden or Italy). The company sources locally grown hops (within 25 miles of the brewery) in its production process as well as uses natural mineral water from its own source. In addition to common industry awards related to the quality and taste of individual beers, the company has won a stream of business awards in various categories ranging from social responsibility and sustainability to service quality and process excellence. According to Shepherd Neame it was the first brewery in the UK to be awarded ISO 14001 accreditation for sustainable management. The company has strong links with the local community through, procurement, employment, pubs and various sponsorship activities. It directly employs about 1,100 people. In its corporate marketing activities the company frequently stresses, amongst other things, its local origin, its heritage and family business credentials, its dedication to quality and its role as a responsible corporate citizen. 
Table 3: Overview of interviews conducted

\begin{tabular}{|c|c|c|c|c|}
\hline Interviewee & Position & $\begin{array}{l}\text { No. of } \\
\text { interviews } \\
\text { (thereof } \\
\text { audio } \\
\text { recorded) }\end{array}$ & $\begin{array}{l}\text { Interview duration } \\
\text { total in min. } \\
\text { (thereof audio } \\
\text { recorded) }\end{array}$ & $\begin{array}{l}\text { Interview dates } \\
\text { (all in 2010) }\end{array}$ \\
\hline 1 & Company President & $2(1)$ & $\sim 125$ (45 recorded) & $20^{\text {th }}$ July \\
\hline 2 & Chief Executive Officer & $2(1)$ & $\sim 120$ (60 recorded) & $5^{\text {th }}$ May $\& 17^{\text {th }}$ Aug \\
\hline 3 & $\begin{array}{l}\text { Managing Director Property \& Tenanted } \\
\text { Trade }\end{array}$ & 1 & 95 & $19^{\text {th }}$ July \\
\hline 4 & Managing Director Marketing \& Sales & 1 & 62 & $19^{\text {th }}$ July \\
\hline 5 & $\begin{array}{l}\text { Managing Director Production \& } \\
\text { Distribution }\end{array}$ & 2 & 122 & $20^{\text {th }}$ July $\& 28^{\text {th }}$ Sep \\
\hline 6 & Account Director Public Relations & 1 & 78 & $19^{\text {th }}$ July \\
\hline 7 & Account Manager Public Relations & 1 & 55 & $27^{\text {th }}$ Aug \\
\hline 8 & Account Manager Public Relations & 1 & 45 & $27^{\text {th }}$ Aug \\
\hline 9 & Marketing Manager & 1 & 51 & $24^{\text {th }}$ Aug \\
\hline 10 & Business Development Manager & 1 & 75 & 22th Sep \\
\hline 11 & Business Development Manager & 1 & 78 & $5^{\text {th }}$ Oct \\
\hline 12 & Head of Property Services/Architect & 1 & 86 & $28^{\text {th }}$ Sep \\
\hline 13 & Head of Visitor Centre \& Hospitality & $2(1)$ & $\sim 90(60$ recorded $)$ & $5^{\text {th }}$ Oct \& $9^{\text {th }}$ Nov \\
\hline 14 & Company Archivist/Historian & $2(1)$ & $\sim 125$ (65 recorded) & $20^{\text {th }}$ July $\& 17^{\text {th }}$ Aug \\
\hline$\Sigma$ & & $19(14)$ & 1206 (977 recorded) & \\
\hline
\end{tabular}

Table 4: Corporate Heritage Identity Stewardship awareness dimensions and dispositions

\begin{tabular}{|l|l|}
\hline CHIS dispositions & CHIS awareness dimensions \\
\hline $\begin{array}{l}\text { Sense of Continuance } \\
\text { Sense of Belongingness } \\
\text { Sense of Self }\end{array}$ & Positionality Awareness \\
\hline Sense of Heritage & Heritage Awareness \\
\hline $\begin{array}{l}\text { Sense of Responsibility } \\
\text { Sense of Potency }\end{array}$ & Custodianship Awareness \\
\hline
\end{tabular}




\section{FIGURES}

\section{Figure 1: The process of data analysis}

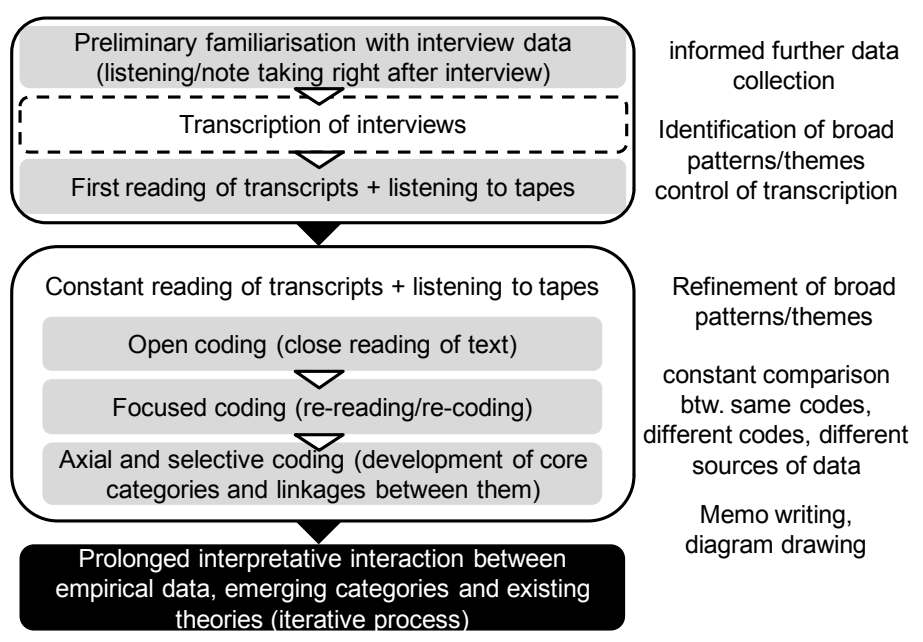

Figure 2: From open coding to conceptual categories

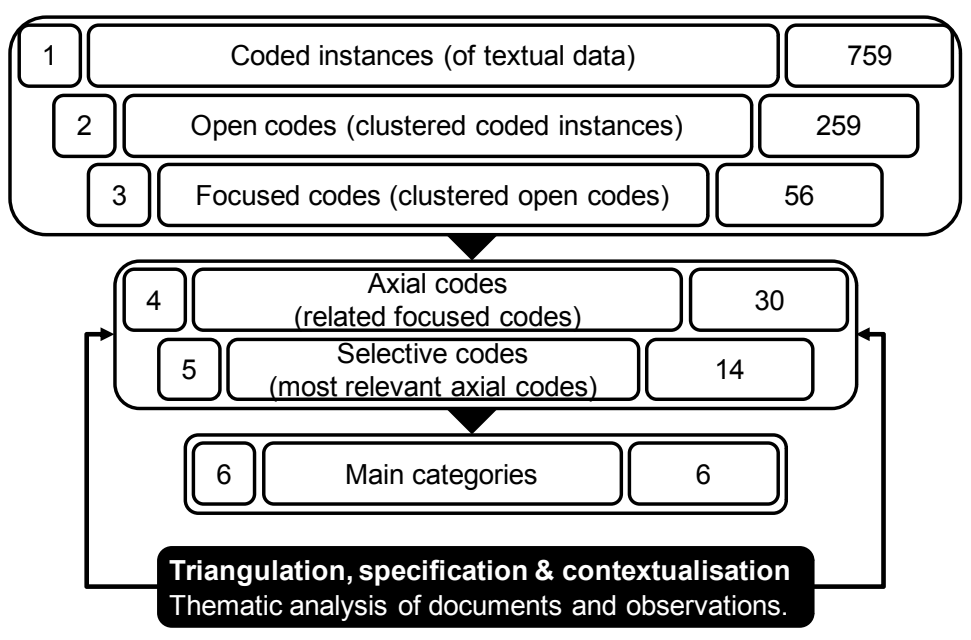


Figure 3: The corporate heritage identity stewardship theory (theoretical framework)

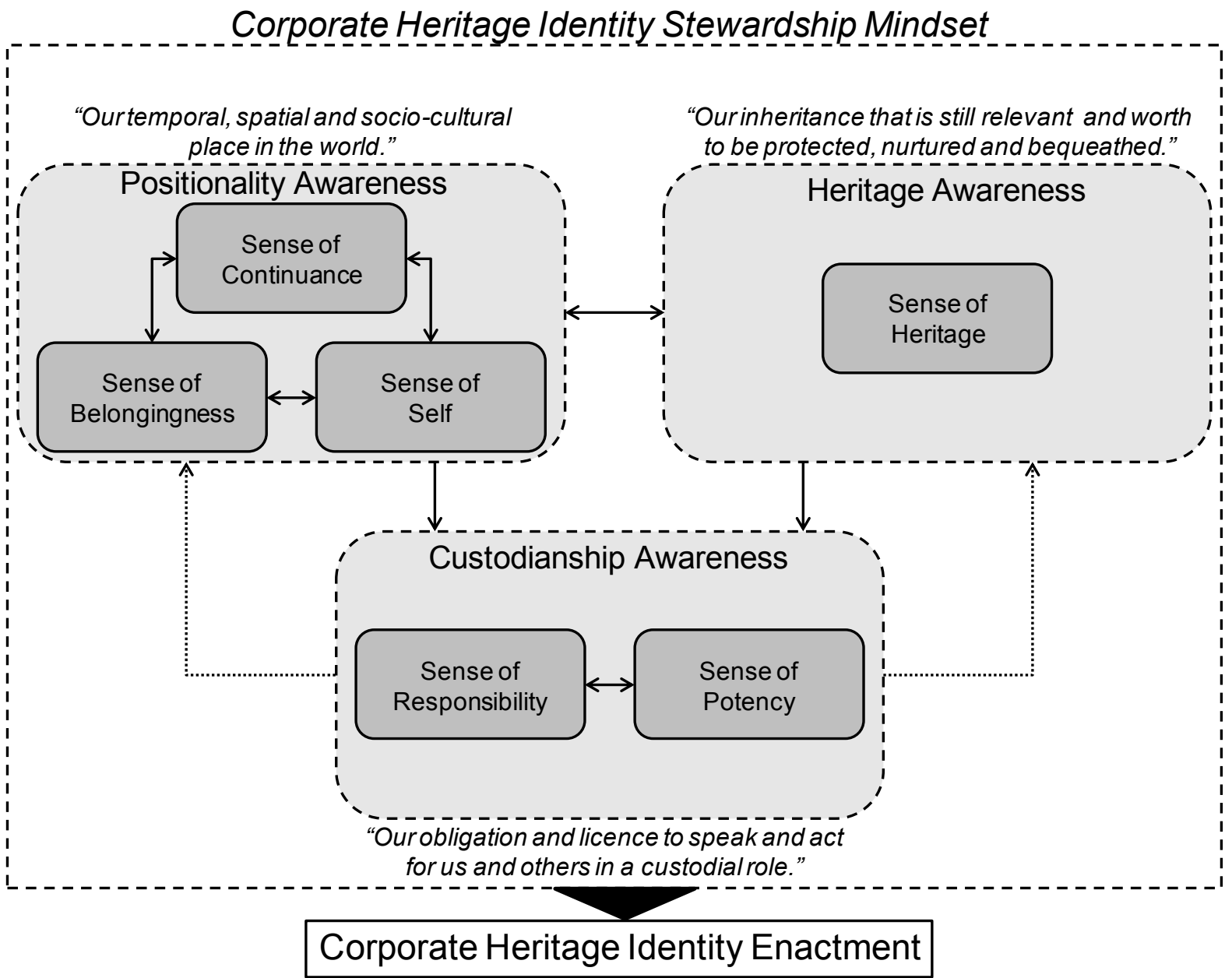

